\title{
Exploring Discourse Markers in the Noble Quran: Some Verbal Clues that Facilitate Logical Hedging, Linguistic Interaction and Language Politeness
}

\author{
Sami Al-Heeh* \& Mahmoud Itmeizeh \\ Department of English, Palestine Ahliya University
}

*Corresponding Author: Sami Al-Heeh, Department of English, Palestine Ahliya University

\begin{abstract}
From a pragmatic perspective, this small-scale study investigates the discourse markers used in the Quranic discourse. It aims to conceive some bare minimum words namely ('an, 'in, la:, li-, ma: and ha-) as discourse markers. Traditionally, Arab linguists often classified them as extra words because of their minute word-formations to convey certain meanings. Based on more recent denotational and morphological theories, the study theorizes that they must be morphemes, i.e. smallest units of words that carry meaning, sustained on the discourse level of some specific contexts for some pure linguistic reasons. The study uses key word in context (KWIK) for data collection. It applies a critical discourse analysis (CDA) approach to the data collected. It uses Fairclough's 2010 and Van Dijk's 1998 models of analysis on the syntactic, semantic and schematic level. It has been found that the minimal words are unlikely to be extraneous or erroneous. They constitute an important linguistic element of some discourses negotiating contexts characterized by hypersensitivity. Stylistically and pragmatically, the Quranic discourse utilizes them schematically to meet the requirements of logic for hedging, to satisfy the needs of participants for linguistic interaction and to show inclinations of people to language politeness. Finally, the study implicates for research on pragmatics and translation studies.
\end{abstract}

Keywords: The Quranic discourse, critical discourse analysis (CDA), discourse markers, hedging, language interaction and politeness

\section{INTRODUCTION}

Discourse can be defined as a unit of language above that of the paragraph. Thus a piece of discourse may consist of one or two words or hundreds or even thousands of words, as a novel might be. A typical discourse lies somewhere between these limits of words (Hinkel and Fotos, 2001). Discourse refers to the way in which language is used in a social context to satisfy broad meanings. Language is usually identified by the social factors, such as the participants of the talk and the message they are trying to convey. In this sense, language is unlikely to be 'neutral' as it 'bridges our personal and social worlds' (Henry and Tator, 2002).

The term discourse can also be used to refer to a context of language or a topic in particular. Where the term stands for a concept, it is usually felt as a genre or text type. For example, certain homely genres such as the wedding invitation cards, obituaries and birthday cards conceptualize social discourses, i.e. kind of language features and moves used in these social acts. Besides, discourses can be conceived according to the topics they discuss. Regardless of the genre, environmental discourse for instance, may find its way in media, business or literature. Such as a discourse often suggests positive attitudes towards the ecosystem including protecting the environment rather than wasting resources. By the same token, Foucault (1972, pp. 315-335) refers to discourse more ideologically as "practices which systematically form the objects of which they speak".

For many researchers the term 'discourse' is often used interchangeably with 'text'. Thus both terms can refer to a piece of language whether spoken or written. However, discourse is sometimes contrasted with text to refer to the whole act of communication which involves the processes of producing and comprehending a piece of language on one hand. On the other, text is used to refer to the actual final written or spoken product. In relevance, the study of discourse can involve studying 
Exploring Discourse Markers in the Noble Quran: Some Verbal Clues that Facilitate Logical Hedging, Linguistic Interaction and Language Politeness

certain aspects related to the context, background information and knowledge shared between the interlocutors, i.e. speaker and hearers, of any communicative activity (Bloor and Bloor, 2013).

Central to discourse is the 'common ground of the participants' (Renkema, 2004). Discourse is, therefore, more than a message between a speaker and a listener. In any discourse, participants are best referred to as metaphors that baffle what is going on in a language activity. Specific illocutionary forces, i.e. non-linguistic elements related to requesting, criticizing, directing, for instance, have to be linked to the message according to the situation in which the discourse is taking place. The linguistic activity is tackled to call for the participants' common ground. In brief, common ground is the mutual knowledge, attitudes, thoughts between people interacting verbally.

A discourse marker is a particle, (e.g. well, I'm afraid, right, actually) that interlocutors or writers use to direct or redirect the stream of discourse without adding any significant paraphrasing or defining meaning to the discourse. The discourse marker is often referred to as a 'verbal clue' or 'pragmatic marker' (Schmitt, 2010). From a semantic perspective, discourse markers are not pivotal to meaning, so they can neither be referred to as 'categorematic' words that carry meaning nor as 'syncategorematic' words that help modify meaning (Kearns, 2000). Besides, discourse markers are syntactically independent. Their independency highlights that fact that their removal on the syntactic level will leave the sentence intact. This interpretation suggests that pragmatic markers can be isolated as disjunctions.

Discourse markers are intended to serve different purposes. They include language "interaction, politeness and hedging" (Schmitt, 2010, pp. 55-73). Verbal interaction usually takes place in adjacent patterns where one speaker takes a 'turn', i.e. a social act before he or she handles it to another. To facilitate the process of giving and taking turns, people sometimes tend to use verbal clues, such as 'right?', and 'What do you think?', for instance. Sometimes they disagree with others, so they tend to express their disagreement politely as in 'Actually, he is not a friend of mine'. The adverbial clause 'actually' can only mark politeness. Finally, hedging is also likely. Generally speaking, hedging enables the speakers to either ally themselves or get themselves distant of what is being said. Hedging may also allow for other possible, but true opinions to be furthered. For example, one may express an idea tagging it with the phrase 'I am afraid' just to admit other tangible ideas.

Wang (2011) studied the discourse markers that have affective rather than informative functions on language learners. Applying a discourse-pragmatic approach, the researcher checked both the Kanji, i.e. Japanese discourse marker ano and the mandarin Chinese nage in conversational discourses. Both markers are derived from adjective phrases similar to 'that' in modern English. By examining more than five-hundred examples in natural conversations, the researcher found that both markers serve as verbal fillers to introduce a new topic in highlighted but less imposing way, to navigate different face threatening acts, and to signal for hesitation when sharing personal information. The researcher concluded that both discourse markers are used for a politeness as well as a modality purpose.

Hum et. al (2014) investigated the use of namely 'Oh' and 'Well' as pragmatic markers in the conversation carried out by the students at Bandung State Polytechnic. By applying a qualitative as well as a quantitative method and using a descriptive-interpretive approach, the researchers analyzed the students' use of 'oh' and 'well'. They found that the verbal clue well was mostly used as face-threat mitigation marker. This discourse marker was not, however, used as a qualifier attempting to signal for any problems in the previous utterance. In turn, the marker 'oh' was mainly used to express pure surprise. Other potential functions for 'oh', such as assertion, reaction and emphasis were unlikely. The researchers also found that 'oh' was more frequent or rather redundant than 'well' among the Indonesian students' conversations.

From a functional view, Guo (2015) reviewed some academic papers carried out on discourse markers in the last few decades. The study examined the discourse markers, their linguistic features, their properties and functions. The researcher first described the discourse markers used in the conversations examined by other researchers. Then he interpreted their functions according the findings of those studies. The researcher finally attempted to explain their uses in English by summarizing the research foci and approaches. The study has concluded that the use of discourse markers in English is mainly characterized by flexibility and multi-functionality. 
Exploring Discourse Markers in the Noble Quran: Some Verbal Clues that Facilitate Logical Hedging, Linguistic Interaction and Language Politeness

\subsection{Research problem, objectives and questions}

Though concise, the Quranic discourse markers have already (to my best knowledge) received less interest by scholars in pragmatic and translation studies. To bridge the gap as well as void in literature, this small-scale study aims at describing the discourse markers -if any, that are used in the holy Script of Islam, interpreting the language functions they help further and explaining the linguistic forces that help insert them on the syntactic level. Therefore, the study addresses the following questions:

1. What are the potential discourse markers that are used in the Noble Quran?

2. What language properties does the Quranic discourse marker have?

3. What language functions do the Quranic discourse markers serve?

4. What are the sociolinguistic factors and forces that help admit them on the syntactic level?

\subsection{Significance of the study}

In pragmatics, the study counts. It is the first that attempts to quantify the discourse markers in the holy Script of Islam from a pragmalinguistic perspective. It investigates some words which are traditionally assigned as extra morphemes by the scholars who interpreted the meanings of the Noble Quran, e.g. Al-Mahali \& As-Sayuti and Al-Qurdubi. According to these linguists, these words look extraneous as they neither carry nor help modify meaning. They also manifest themselves as bits of words, such as 'in', 'an', 'la:' and 'li' for example. On the syntactic level of the Quranic discourse, some verses are sometimes identical except for the so called 'extra' word used. Absent the minimal, each pair seems redundant. It is important to note here that the use of these words don not entail any contradiction on the logical level. For example, the word 'la:' meaning 'not' in the Quranic clause 'la: uqsumu' meaning 'I don't swear' is perceived by the native speaker of Arabic as "I swear'.

In translation studies, the investigation also minds. The Quranic discourse is the main reference of more than one billion Moslems. Most of them are non-native speakers of Arabic, though the language of Islam, i.e. Arabic is used as lingua franca. This demographic distribution has led to interpret the Quranic discourse into more than forty languages including the international ones. As English is a global language, more than ten interpretations have been carried out in English recently. In these copies, interpreters tend to (due to lack of knowledge from the mother source) apply certain strategies to conceive the Quranic discourse 'marker'. Sometimes, they circumnavigate the extra word by using the English equivalent as a disjunt (e.g. Nay, I swear..). More frequently, they totally disregard the target word.

\subsection{The Quranic discourse}

The Quranic discourse consists of one-hundred and fourteen chapters. Chapters vary a lot in length, style and context. Each chapter is typically divided into some verses extending from only 3 (Al-'Asr: 103) to 286 (Al-baqarah: 2). The former including only 20 words, is usually referred to as the shortest; the latter consisting of thousands of tokens is the longest. Though the vast majority of the Quranic discourse uses a pure narrative style (Yusuf:12), many chapters apply a mixed style aiming to draw some lessons from some historical events. The Quranic discourse clearly applies a journalist style as in (Al-baqarah:2), an essay style like (Al-waqi'ah: 56) and an academic or abstract style as in (Alfatihah:1). Language functions also vary considerably. It can be referential, directive, affective, expressive, performative, heuristic and meta-linguistic, for instance.

\section{RESEARCH METHOD}

The paper builds on discourse analysis (DA) as research method. DA (also known as text analysis) is a way of examining "records of spoken or written text to see if they suggest that the surface utterances are representative of underlying processes (Beatty, 2003, pp 125-131). DA is "the analysis of language in its social context" (Schmitt, 2010, pp 55-73). Discourse analysts mind the relationship between texts and context in which they emerge and function. They usually examine texts whether short or long. They also concern real authentic, i.e. real texts in a way which is completely different from linguists who are often stuck to the notion of sentence. 
Exploring Discourse Markers in the Noble Quran: Some Verbal Clues that Facilitate Logical Hedging, Linguistic Interaction and Language Politeness

A recent thrust in language research is critical discourse analysis (CDA). Many researchers, such as Fairclough, 1992, 1995, Van Dijk, 1998 and Wodak, 1999, have been intimately linked with CDA,. As a branch of discourse analysis rooted in critical linguistics, CDA surpasses the description and identification of the component of the text to the deconstruction and exposition of the social values, beliefs and practices that moulds the selection and arrangement made in the construction of one specific text. For a careful discourse analyst, CDA also clarifies all of the user's choices preferred to be taken in the process of constructing a specific discourse. To Fairclough (1992, p.12), discourse is not only felt as a reflection or a product of social acts, but it is also "shaped by relations of power and ideologies" or thoughts expressed in the text. Similarly, Pennycook (1994, p. 121) makes an effort to develop a general outlook for CDA that mirrors "the larger social, cultural, and ideological forces that influence our lives". Pennycook adheres that approaches to CDA "share a commitment to go beyond linguistic description to attempt explanation, to show how social inequalities are reflected and created in language" (ibid. p. 121).

\subsection{Data collection and analysis}

The paper benefits from corpus linguistics, i.e. large bodies of texts. Therefore, it examines the Quranic discourse translated in English for key words in context (KWIK). Concordance includes looking for the words that have traditionally been stigmatized as 'extra' words. The study highlights but not exclusively the following minimal words: 'in' vs. 'an', 'la:' vs. 'li-', 'ma:' and 'min' and 'ha-'. It is important to note here that these Semitic words, henceforth, Arabic discourse markers (ADMs) can appear as free or bound morphemes on the syntactic level. Semantically, ADMs can also be used as functional words expressing (respectively) certain meanings such as linguistic endorsement, participial phrasing, logical contradiction, i.e. negation, possession, paraphrasing, laughing or silence and assistance. As a procedure, the potential meanings of ADMs referred to above will be acknowledged and excluded from any discussion related to the use of these minimals as ADMs.

The study draws on Fairclough's 2010 and 2013 as major part of the analytical tool to link the 'microanalysis' of the text with the various 'macro-relations' of the thoughts the Quranic quotes attempt to express (2010, p. 132). This three-dimensional analytical framework displays discourse simultaneously as a language text (written or spoken), discourse practice (text production and interpretation), and socio-linguistic practice (see Figure 1). In this view, Fairclough's model of analysis aims at revealing meaning at three levels: Meaning production, consumption and realization. At the first level, analysis is geared towards interpreting the rhetoric features of the text. At the second, analysis regards describing the meaning relations drawn in the text. At level three, analysis attempts critically to explain the factors and forces that help advance certain linguistic formulas and expressions.

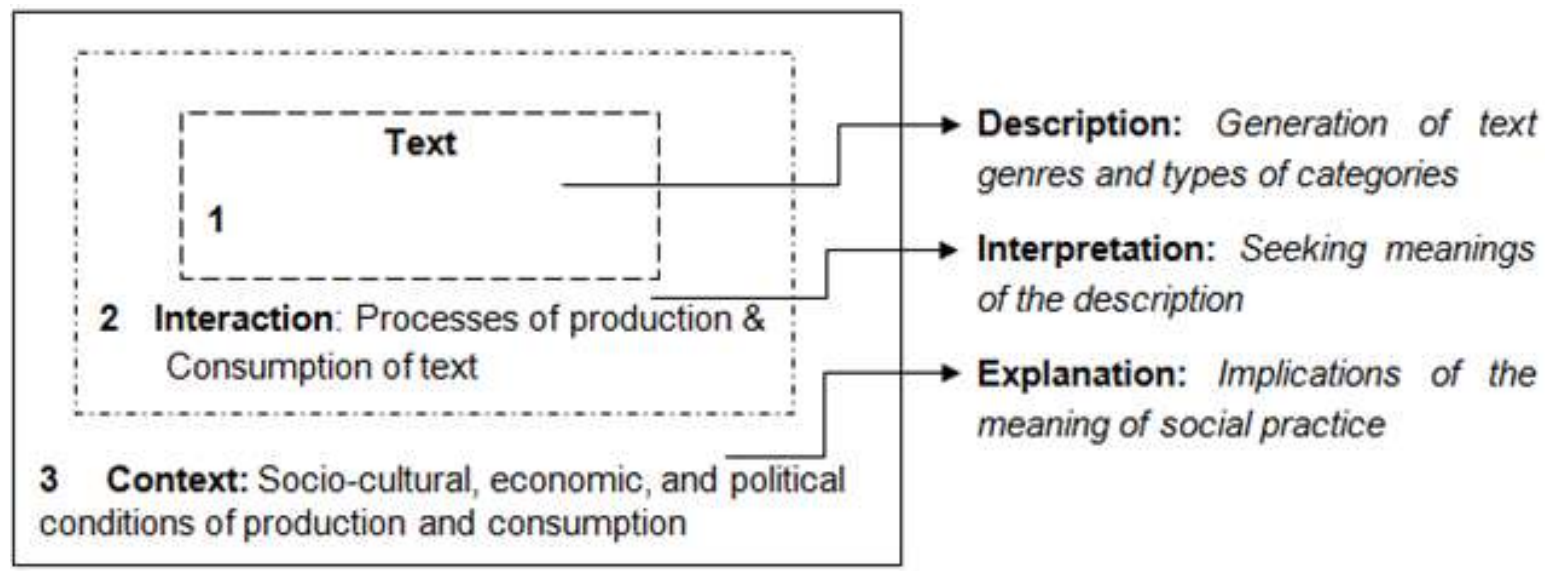

Figure1. Fairclough's 2003 Analytical Framework

In compatible with Fairclough's 2003 analytical framework, is Van Dijk's model of analysis. Van Dijk (1998) has pointed out to a variety of discourse structures that can carry important functions of ideology or identity. These respectively include syntactic, semantic and schematic analyses. Syntactically, pronouns, for example, can mirror the group's' ideological membership. The use of the pronoun 'us' vs. 'them' definitely reflect in-group, sharing interests and out-group competing ones, respectively. The syntactic markers showing politeness (vous) in French and (tu) in Spanish also 
Exploring Discourse Markers in the Noble Quran: Some Verbal Clues that Facilitate Logical Hedging, Linguistic Interaction and Language Politeness

reflect certain types of repertoire. Semantically, the solid discourse of opinions, thoughts, and ideologies is persuasive in nature. The lexical choice between 'terrorists' and 'freedom fighters' usually reflect a negative, out-of-group and a positive, in-group look at one group of people. Schematically, certain thoughts can be expressed at the discourse level. The words selected and used in the title of a news story can strongly demonstrate the newspaper's view on the news event. Therefore, it is more important to regard a chunk of text and to recognize what it acknowledges rather than know what a discourse generally attempts to satisfy.

\section{CRitical ANalysis AND Discussion}

This chapter aims at quantifying as well as qualifying the discourse markers used in the Noble Quran. To address the research questions properly, the chapter is divided into six sections. In each section, critical analysis is furthered to cover the syntactic, semantic and schematic features of the quotes under discussion, respectively. This systematic analysis and presentation is expected to reveal how meanings of the discourse marker is produced, consumed and construed, i.e. realized (for more information, see Appendix A). To be consistent, the term Arabic discourse marker (ADM) is flavored as the holy Script of Islam was originated precisely in classic Arabic. This procedure enables the analyst to contribute to both linguistic and religious studies. Transliterations for the quotes are also provided for the non-native speakers of Arabic.

\subsection{The ADM ['in]}

In Classic Arabic, the morpheme ['in] functions as infinitive marker. It usually heads the present participle to form a verb phrase (VP) with ['in] as in ['in tadrus..] glossed as (if you study...). The VP is syntactically unmarked where the formula is used as a conditional clause. Where the VP is past participle, the morpheme ['in] is, however, unlikely. Notably, the stressed form ['inna] glossed as 'verily' or 'indeed' is used for endorsement.

In quote $1 \mathrm{~A}$, the word ['in] heads a past participle VP, so it is unlikely to be a conditional marker. It serves no clear grammatical function on the sentential level, and it fits into no functional category. It however takes place in a relative clause headed by [ma:] meaning [fi: al-athi:] meaning (in what). This clause is headed by a preposition and is coordinated with another clause. The personal deictic pronoun [-hi] refers cataphorically, i.e. forward to address a category of things to be discussed later. Therefore, this word takes place in a discourse, i.e. a unit of language above that of a sentence. In relevance, it is important to note here that [ma:] is a homophone that can be used as a relative pronoun and a negative marker.

Quote 1A [wa-laqad makkannahum fi:-ma: 'in makkannahum fi:-hi wa-ja'al-Na lahum sa'm'an wwaabsa: ran wwa-'af'idatan..] Al-Ahqa:f 46:27

(And we had established them in what We have established you not; and We gave them ears and eyes and hearts...)

The predicate [makkaNa:hum] is repeated twice. It means (established), and it argues first for both (We) referring to Allah and (them) referring to a group of people, then again for (We), (you) referring to another group of people and (it) referring to something or a category of things. The predicate is a two-place and three-place VP, respectively. It is important to note here that the interpreters of the Quranic discourse perceive ['in] as [ma:] meaning not (see the English interpretation of Quote 1A). However, the word ['in] neither denotes [not] nor connotes the feeling of logical contradiction (of not).

From both a semantic and a syntactic perspective, the ADM ['in] is unlikely to be categorematic, i.e. functional word that carries a full meaning or a syncategorematic, i.e. grammatical word that helps modify meaning .As this ADM turns speech from one group of people to another, it sounds that the Quranic discourse uses ['in] as a verbal clue to argue positively for one group of people who was given certain auditory and emotional abilities such as hearing, sight and hearts rather than another previous group. The insertion of this ADM might also hedge for the potential deaf, blind and unkind members in both groups. In case, it also keeps a positive face, i.e. respect for the potential disabled of -on the basis of using this marker to the right of- the 'you-group' which refers to the new emerging Muslims. It is important to note here that the Quranic discourse refers positively to the disabled. 
Exploring Discourse Markers in the Noble Quran: Some Verbal Clues that Facilitate Logical Hedging, Linguistic Interaction and Language Politeness

To suffice, quote 1B also presents the ADM ['in]. In Arabic, ['inna], the stressed form of ['in] is an endorsement element . It is used to head the sentence when the style is nominal. Grammatically, this endorsement element is followed by two words functioning as subject and subject complement. Syntactically, the NP functioning as subject is marked for the accusative case with [-a, -an, -ayni, -i: na] when the subject is definite singular, indefinite singular, dual and plural, respectively. The NP functioning as complement for the subject is differently marked for the nominative case with [-u, -un, -ani, -u: na] when the complement is definite singular, indefinite singular, dual and plural, respectively. In verse 64, the syntactic rules referred to above are blocked on the Arabic phonemic (but not graphemic) level though the unstressed endorsement element ['in] is furthered and sustained (see quote 1B). This syntactic blockage has mandated that verse 64 have a grammatical error.

Quote 1B [fa-tanaza'u: 'amrahum baynahum wa-'asarru: an-najwa: * qa:lu: 'in hatha:ni la-sa:hira:ni yuri:da:ni 'an..] TaHa 20:63-64

(Then they argued their affair among themselves and conferred in secret * They said, 'Certainly these two are magicians, who..)

On the discoursal level (of both verses), the predicate [tana:z'a] meaning (he argued) is assigned for [u:] referring to old Egyptians and [amra-hum] meaning (their affair) and [bayna-hum] meaning (among themselves), so it is a three-place predicate. The predicate [asarra] meaning (he conferred) is assigned for (them) and [an-najwa:] glossed as (to themselves or in secret). It is a two-place predicate .The predicate [qa:la] meaning (he said) is assigned for [-u:] referring to (Egyptians who kept the fair) and a reporting clause. This predicates is two-place.

Quote 1B reports the debate taking place secretly among Egyptians who suspects two people from Sons of Israel as magicians. They demonstrate to or rather finally denounce Moses and his brother, Aaroon as potential magicians. The concept of magic is endorsed by the [la] also known as a slippery endorsement element in Arabic.Demonstrating to the true magician (whether Moses, his brother or both) is carried out by [hatha:ni] which functions as an endophoric, textual reference (a quantified, human or non-human element). In modern languages, demonstrative pronouns must also show what belongs to someone, what belongs to others and what is neutral.

As old Egyptians failed to make up their minds about the true magician, it seems that the Quranic discourse reports what was exactly going on. It first handles the turn to that group to express their inner thoughts secretly. Then it hedges by ['in] to mark verbally their disagreement about the true magician. Hedging here aims at quantifying their speech. It finally certifies what they agreed upon. The graphemic clues sustained on the discourse level (of the Arabic copy) probably show both how Arabs used to spell words and how they say words, but not in any case what words mean.

Schematically, the quote manipulates the theme of magic both Moses and his brother were accused of doing to persuade Egyptians. This helps explain the use of the nominal style which looks very informative in the second verse. The style used aims to load certain meanings related to the theme which is already endorsed by the slippery element [la]. However, the use of the exophoric reference [hatha:ni] glossed as 'those' attempts to link between the real act (of magic) and performer. Throughout the holy Scripts of Judaism, Christianity and Islam, It is well known that only Moses was able to do certain miraculous acts. The brother, $[\mathrm{H}]$ aroon was, however, not supposed to. Actually, he was assigned as an assistant as he was more fluent than Moses. In Arabic, the phrase [sihru alkhita:bi] also means 'fluency or charm of speech'.

\subsection{The ADM ['an]}

In Standard Arabic, the morpheme ['an] is used as infinitive marker. It heads the present participle verb phrase to form an infinitive verb phrase (Inf-P). The Arabic Inf-P with ['an] is similar to the English Inf-P with 'to'. Functionally, the Arabic Inf-P is used to show action. For example, the formula ['an tadrus] meaning 'to study' tells how. However, the phrase can be converted into a noun phrase (NP), such as [dira:satuk] meaning 'your study' to express what. In Arabic, the Inf-P has the general characteristics of verbs. Functionally, the NP derived from the Inf-P behaves similarly on the syntactic level. Thus, the Semitic ['an] is unlikely to be followed by a past tense to show an action or an action in progress. 
Exploring Discourse Markers in the Noble Quran: Some Verbal Clues that Facilitate Logical Hedging, Linguistic Interaction and Language Politeness

Though the opening of both quotes is identical, quote 2A furthers ['an] as an extra word (see the Arabic transliteration for quote 2A). This word takes place in the dependent clause (and when..); the clause continues to present some events in sequence. The sequence ends in a directive clause (Fear not!). Then it continues in a nominal style that informs saving Noah and his family. Finally it excludes his wife and other people.

Quote 2A [wa-lamma: 'an ja:'at rusuluna: lu:tan si:'a bihim wa-da:qa bi-him thar'an wwa-qa:lu: 'inna: munajju:ka wa-'ahlaka 'illa imra'tuka kanat min al-ghabri:na] Al-Ankabut 29:34

(And when Our messengers came to Lot, he was distressed on account of them and felt powerless with regard to them. And they said, 'Fear not, nor grieve; we will surely save thee and thy family except thy wife, who is of those who remain behind.)

Quote 2B [wa-lamma: 'an ja:'at rusuluna: lu:tan si:'a bihim wa-da:qa bi-him thar'an wwa-qa:la hatha: yawmun 'asi:bun] Hud 11:78

(And when our messengers came to Lot, he was grieved on account of them and felt helpless on their behalf and said, 'This is a distressful day.')

The predicate [ja:'a] meaning (he came) is assigned to argue for [rusulu-Na] meaning (our messengers) and [lu:tan]. It is a two-place predicate. The predicate [si:'a] roughly glossed as (mistreated or be harassed by) argues only for (-him] referring to (the messengers). It is a one-place predicate. The predicate [da:qa] glossed as (he felt powerless regard) is assigned to argue for both (he) referring to Lut and (-him) referring to the messengers, so it is a two-place predicate. The predicate [qa:la] meaning (he said) is assigned to argue for [-u:] referring the messengers and the directive [la: takhaf] meaning (fear not).

The word ['an] heads a sequence of events in which some guests arrived, were mistreated (by some other locals) and the host felt helpless. As the dramatic situation has reached the peak on which the host felt powerless to protect his guests, the Quranic discourse has paved the way to give the turn to the guests themselves. Taking the turn, the guests redirect their host not to feel panic or sad and that they will save their host and his family except the wife. In this sense, it sounds that ['an] is a verbal marker employed by the Quranic discourse to enable interaction in the right moment.

To proceed, the word ['an] inserted at the beginning of quote $2 \mathrm{C}$, takes place in a dependent adverbial clause headed by [fa-lamma:] meaning (when he). The main (also known as matrix) clause is headed by [qa:la] meaning (he said). This VP is a reporting one. The reported clause can be perceived as a condemning interrogative. In the dependent clause, the VP [ara:da] glossed as (he made up his mind) is paradigmatic. Here, it expresses a decision. Thus, it is cognitive. In the main clause, the VP ['auri:du] meaning (Do you intend?) is felt as a willingness verb aiming to express a desire or want. It is important to note here that the word under investigation is homo-phonous. It only heads the present but not past participle. Therefore, this word has shown neither grammatical function nor language category.

Quote 2C [fa-lamma: 'an ara:da 'an yabtisha bi-alathi: hu:wa 'aduwwun llamuma: qa:la: ya: mu:sa: 'aturi:du 'an taqtulani: ka-ma: qatalta nafsa(m) bi-al'amsi 'in turi:du 'illa: 'an taku:na jabba:ran fi: al'ardi wa-ma: turi:du 'an taku:na min-al muslihi:na] Al-qas:s 20:28

(And when he made up his mind to lay hold of the man who was an enemy to both of them, he said, 'O Moses, dost thou intend to kill me as thou didst kill a man yesterday? Thou only intend to become a tyrant in the land, and thou intend not to be a peacemaker.')

The predicate [ara:da] meaning (he decided) is assigned to argue for (the unstated [-hwa]) referring to Moses and the (infinitival phrase ['an yabtisha] meaning (to kill or Killing). It is important to note here that the relative clause headed by [bi-alathi:] is a specification for the present participle VP [yabtisha]. This predicate is a two-place one. The reporting predicate [qa:la] meaning (he said) is assigned to argue for (the unstated [huwa] referring to an Egyptian, the exclamation phrase (Oh, Moses) and the (interrogative clause). It is a three-place predicate.

It is clear that ['an] takes place in a discourse where a crime is going to be committed soon. It marks a Quranic discourse in which Moses has made up his mind to kill an enemy of his own relative. This 
Exploring Discourse Markers in the Noble Quran: Some Verbal Clues that Facilitate Logical Hedging, Linguistic Interaction and Language Politeness

dramatic decision has accelerated the Quranic discourse to give turn to the Egyptian to interact. Taking the turn, the Egyptian has reminded Moses that is going to commit a second crime, to be tyrant, and not to be a peacemaker.

\subsection{The ADM [ma:]}

In Arabic the morpheme [ma:] is homophonous. It is used as a relative pronoun, a question word, a negation marker and exclamation word. For example, the Arabic clause [ha:ti ma: tahmilu] means 'Give me what you are carrying' consists of a relative clause whereas the clause [ma: tahmilu?] meaning 'What are you carrying?' is interrogative. In the clause 'ma: darastu' meaning 'I didn't study', the phrase [ma:] shows negation. In the clause 'ma: ahsana as-sama:'a!', the phrase [ma:] is used for exclamation.

In quote $3 \mathrm{~A}$, the word [ma:] takes place in an adverbial clause of time headed by [hatta:] meaning (until) which shows the end point of time and the conditional clause headed by [itha:] meaning (when). The main clause is a verbal sentence where three elements consisting of ears, eyes and skins function as coordinated direct objects for the VP [shahid] meaning (bear witness). The second verse begins with a reporting VP [qa:la] meaning (he said). Then, it continues with the same reporting verb where a relative clause is used. The verse ends in a nominal style. The nominal style aims at loading certain meanings related to ontology, i.e. creation of the universe and humans (see the English interpretation for the quote).

Quote 3A [hatta: itha: ma: ja'u:ha: shahida 'alayhim sam'uhum wa-absa:ruhum wa-julu:duhum bi-ma: ka:nu: ya'malu:na *wa-qa:lu: li-julu:dihim li-ma: shahiditum 'alayna: qa:lu: 'antaqana: Allah-u al-athi: 'antaqa kulla shay'in wa-Hwa khalaqkum 'awala marratin wa-'ilay-Hi turja'una] As-Sajdah 41:21-22

(Till, when they reach it, their ears and their eyes and their skins will bear witness against them as to what they had been doing. *And they will say to their skins: 'Why bear ye witness against us?' They will say: "Allah has made us to speak as He has made everything else to speak. And $\mathrm{He}$ it is who created you the first time, and unto Him have you been brought back.)

In the first verse of quote 3A, the predicate [ja'a:] meaning (he came) is a motion VP. It argues for [$\mathrm{u}:]$ referring to (they, i.e. enemies of Allah) and [-ha:] referring to (the Hell), so it is a two-place predicate. The predicate [shahida 'ala:] meaning (bear witness against) is assigned to argue for (ears), (eyes) and (skins) and the relative clause, so it is a two-place predicate. In the relative clause, the predicate [ya'mulu], meaning (he does) argues only for [-u:] which refers to (them), so it is a oneplace predicate. It is important to note here that the meaning relation the verse sustains between the VP (bear witness against) and the arguments (ears, eyes, and skins) is a meronym, i.e. part of whole one. However, it is not anomalous, i.e. strange as this category has the semantic features of humans or animates, so these NPs are included within the semantic features of the VP.

In the second verse, the predicate [qa:la] meaning (he said) argues for Prep-P [li-julu:di-him] referring to (their skins) and the interrogative (why did you bear witness against us?), so it is a two-place predicate. In the interrogative, the predicate [shahida 'ala:] meaning (bear witness against), [-tu] referring to (the skins) and [-na] referring to (us), so it is a three-place predicate. The predicate [qa:la] argues for [-u:] referring to (the skins) and the whole verbal sentence, so it is a two-place predicate. The predicate of the sentence ['antaqa] meaning (made speak) argues for (Allah) and the relative clause). In the relative clause, the predicate ['antaqa] also argues for the unstated (Allah) and (everything). It is important to note here that the argument (everything) is a universal, non-existential quantifier. It must be interpreted as: For every value of $\mathrm{X}$ if $\mathrm{X}$ is something then Allah made that $\mathrm{X}$ speak.

The morpheme [ma:] which is inserted at the beginning of the quote is not used for linguistic relation, exclamation, negation or interrogation. That is to say none of these processes sounds operable on the syntactic level. The verse does not entail any anomalousness, i.e. semantic oddness because it does not violate the selectional rules and does not also entail any contradiction (see Figure 2). Although the semantic value (S-Val) of the Quranic verb phrase (VP) is exceptionally included within that those of the noun phrases (NPs), using parts of the body other than the organs of the articulation system, however, breaks the norms of speech and witness people know. Therefore, it sounds that the Quranic discourse paves the way for a strange way of interaction between a group of people, i.e. enemies of 
Exploring Discourse Markers in the Noble Quran: Some Verbal Clues that Facilitate Logical Hedging, Linguistic Interaction and Language Politeness

Allah, and their own organs and skins. The selection of different organs to bear witness against that group mandates an arrival in groups. The Arabic for [in groups] is [zumar].

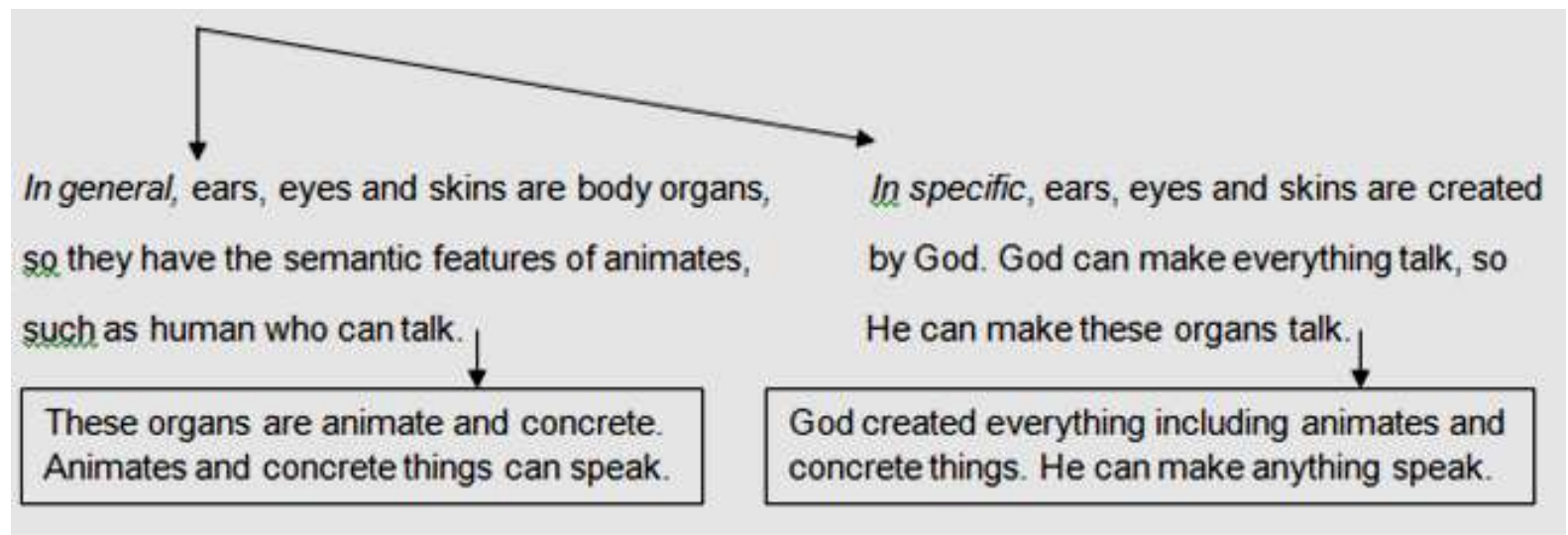

Figure2. Anomalousness, i.e. Semantic Oddness in Quote $3 A$

To press on, quote 3B surprisingly uses the adverb phrase [zumaran] meaning (in groups). It also describes the arrival of a group of disbelievers to the Fire in groups. Unlike quote $3 \mathrm{~A}$, the quote lacks the DMA [ma:]. The quote uses the verbal style, and it consists of a matrix clause and two subordinated clauses. The main clause employs the passive voice. It uses the VP [si:qa] meaning (be driven to). The VP is an action, but intransitive VP that requires an agent, such as [al-athi:na kafaru"] meaning (those who disbelieved), a specification functioning as a motion phrase (Mot-P) and an optional complement phrase, such as (in groups) showing the manner. The subordinated clause functions as an adverb of time. It consists of [hatta:] meaning (until), [itha:] meaning (when), and the VP [ja:'u:ha:] meaning (they reached it). The last clause consists of the reporting VP [qa:la] meaning (he said), the prepositional phrase [la-hum] meaning (to them), and NP [khazanatuha:] meaning (its keepers).

Quote 3B [wa-si:qa al-lathi:na kafaru: 'ila: jahannama zummaran hatta: 'itha: ja'u:ha futihat abwa:buha waqa:la lahum khazanatuha 'alam ya'tikum rusulun ..] Az-Zumar 39:72

(And those who disbelieve will be driven to Hell in troops until, when they reach it, its gates will be opened, and its Keepers will say to them: Did not Messengers from among yourselves come to you..)

Semantically, the quote is conveyed by the predicate be driven which argues for the relative clause those who disbelieved, the prepositional phrase to hell, and the adverb of manner in groups. This VP is intended to be a three-place predicate. The predicate reached argues for they referring to a certain group and it referring to Hell. The VP is a two-place predicate. Finally, the predicate said argues for the keepers of the Hell and the provoking interrogative clause did not Messengers from among yourselves come to you. In this sense, the predicate is a three-place one.

Schematically, the quote comes from a Quranic chapter entitled as [Az-Zumar) roughly (groups). This Arabic word connotes the negative feelings of collective but bad work. In Arabic, it is used mainly to describe a group of felines, such as lions. In the quote as well as the chapter, this word is picked in the proposition to prescribe the entrance of disbelievers into the Fire. It tells who, where and how those skeptic people arrive. In the consequence of the verse, the Quranic discourse handles the turn for the Keepers of Hell to interact verbally with them. Verbal interaction is carried out by asking each group about guidance or following up messengers.

\subsection{The ADM [min]}

In Arabic, the word [min] functions as a preposition. More frequently, it is used to head adverbs of place. In the phrase [min al-madrasati] meaning (from school) for example, the preposition [min] clearly signals for a place. It can also be linked with ['ila:] meaning (to) to show either a motion from one place to another or the start point of time and an end point of time. In the phrase [min almadrasti 'ila: al-bayiti] meaning (from school to home), the preposition [min] shows where the movement took place. Similarly, the phrase [min al-almasa:'i 'illa: alsaba:hi) means (from evening to morning). Less frequently, the preposition is used to express quantity if it heads a proper noun (PN) or a common 
Exploring Discourse Markers in the Noble Quran: Some Verbal Clues that Facilitate Logical Hedging, Linguistic Interaction and Language Politeness

noun phrase (NP). In the phrase [min alma:li], the preposition [min] is glossed as (some money) in modern English.

Quote 4A begins with a Prep-P which is used as a discourse linking phrase in a chapter that narrates shortly the stories of some prophets (see also quote 3B). The quote briefly narrates the story of Sha'ib who was sent to his peoples of Median. The quote shifts to report what the Prophet said to his own people. The reported clause sustains that those people must worship Allah who has no other God but him. The quote goes on to give some directives to those people.

Quote 4A [wa-'ila: madayana 'akha:hum shu'ayaba qa:la ya: qawmi 'ubudu: Allah-a ma: lakum min 'illahin ghayruH, qad ja:a'tkum bayyna:tun min Rabikum fa-'awfu: alkayla wal-mi:za:n..] Al-Ara:f $7: 86$

(And to Midian We sent their brother Shu'aib. He said, 'O my people, worship Allah; you have no other deity but Him. A clear Sign has indeed come to you from your Lord. So give full measure and full weight, ..)

Quote 4B [.. Qa:la ya: qawmi 'ubudu: Allah-a ma: lakum min 'illahin ghayruH, Hu:wa 'ansha'akum min-al ardi..] Hu:d 11:61

(..He (Salih) said: "O my people! Worship Allah: ye have no other god but Him. It is He Who hath produced you from the earth..")

The unstated predicate ['arsala 'ila:] meaning (he sent to) argues for the unstated [-Na] -omitted for a rhetorical, i.e. elipsis purpose) which refers to (Allah), Median referring to the place where (those people) live and Shu'aib, so it is a three-place predicate. The change from place to people aims at widening meaning. The predicate [qa:la] meaning (he said) argues for the interjection phrase [ya: qawmi:] meaning (Oh, my people), the directive clause, and the exclusive clause, so it is a three-place predicate. The predicate ['ibudu] meaning (worship) argues for [-u:] referring to (people) and (Allah), so it is a two-place one. In the exclusive, nominal clause, the bound morpheme $[-\mathrm{H}]$ referring to (Allah) is the predicator which argues for [illah] referring to (any other potential gods), so it is a oneplace predicate.

The insertion of [min] in the exceptional, inclusive style is frequent throughout the Quranic discourse (see quote 3B). It aims at quantifying -if any- other potential gods. In Standard Arabic, the free morpheme [min] can be glossed as (some) in modern English. Lack of this morpheme often conveys the kind as in ['ila:hun] meaning god. On the logical level, the insertion of the preposition [min] helps switch the kind into the bare minimum of the kind. Therefore, the insertion of this morpheme hedges not only for the absence of other gods save Allah but also for the scarcity of finding semi or mini gods. Absent the inserted clause [min 'ila:hin] glossed as (some god), the meaning is conveyed and only for Lordship. It is important to note here that the hedging clause can be referred to as a disjunct on the syntactic level. Disjunct clauses can be isolated on the discourse level as they are used as verbal clues to mark or hedge for other possible ideas.

\subsection{The ADM [la:]}

In Standard Arabic, the morpheme [la:] is a negation marker. One the logical level, negation entails contradiction. Negation manifests itself as the proposition [p] and not the proposition [ p]. For example, the Arabic directive ['udrus] meaning (Study) contradicts [la: tadrus!] meaning (Don't study). Sometimes, the lenguistic element [ka] is prefixed to [la:] to further the atrophic form [ka-lla:] roughly glossed as (Nay! Don't!) in obsolete English. This emerging form is used for rebuke.

Quote 6 contains the Quranic expression [la: uqsimu bi-] literally meaning 'I don't swear by' (see quote 6A). This formulaic expression is used seven times in the Quranic discourse, e.g. Al-Haqqah 39:69, Al-Balad 90:2. However, the quote consists of three clauses. The first is verbal. It sounds negative as it uses the logical contradiction marker [la:] meaning (no) or (not). The second is nominal and entails both addition carried out by [wa-] meaning (and) and endorsement as it uses both ['inna] glossed as (indeed) and the slippery marker [la-] roughly glossed as (verily) in modern English. The second clause is also interrupted by a conditional clause glossed as (if only). The third is also nominal. It only entails endorsement carried out by [inna] and the slippery marker [la-]. It is important to note here that [inna] belongs to a category of family-resembling words like [inna, lakinna, layta, la'ala.. etc.] aiming to endorse the nominal style in Arabic. 
Exploring Discourse Markers in the Noble Quran: Some Verbal Clues that Facilitate Logical Hedging, Linguistic Interaction and Language Politeness

As the English interpretation of the Quranic verses reveals, the negation marker [la:] is referred to as a disjunction. This helps explain why it is isolated by a comma. It is a negation marker. Negation is a logical term entailing the proposition (p) and not (p) on the semantic level, so the proposition (I swear) for example, can be negated by (I don't swear) once a negation marker is used. Though it necessitates contradiction, the quote (I don't swear) is perceived (by the native speakers of Arabic) as 'I swear'. This also helps explain why the interpreters of the Quranic discourse consider it as a disjunction.

Quote 5A: [fa-la: uqsimu bi-mawaqi'I an-nuju:mi] Al-Waqi'a 56:75

Nay, I swear by the shooting of the stars

B: [wa-inahu laqasamun law ta'lamu:na athi:mun] 76

-And, indeed, that is a grand oath, if you only knew

C: [inhahu: la-qur'anun kari:mun] 77

- That this is indeed a noble Qur'an,

In quote 5A, the predicate [la: 'uqsimu] roughly glossed as (I don't swear) argues for the unstated pronoun [ana:] referring to (I) and the Prep-P (by the shooting or settings of the stars), so it is a twoplace one. It is important to note here that the deictic personal pronoun (I) can refer to (anyone) who swears. In quote $5 \mathrm{~B}$, the predicator [la-qasamun 'athi:min] meaning (verily a great oath) argues for the bound morpheme [-hu] referring anaphorically, i.e. backward, to (swearing by the shooting stars). The meaning value of the endorsed quote can be interpreted as: There is at least one $\mathrm{X}$ and that $\mathrm{X}$ is an oath by the shooting stars and that $\mathrm{X}$ is great. In the inserted conditional clause, the predicate [t'alam] meaning (if you only know) argues only for [u:-n] referring to (you), so it is one-place predicate. The argument (you) can refer to any addressee. The inserted conditional clause sounds binary. It can be interpreted as: Swearing by the shooting stars is great if you only have some knowledge about. In quote 5C, the predicate [Quranun Kari:min] glossed as the Noble Quran argues for [-hu] referring the Knowledge presented in the Noble Quran.

Quote 5B sustains that people don't have full knowledge of the settings of the stars, so they can't swear by them. This interpretation maintains that pledging is a personal act that requires a conscious knowledge to further wit-nesses in any social act. In turn, pledging is a great act as it builds on providing some true, sincere and credible sources. Therefore, swearing by the shooting stars is unlikely as it lacks true and accessible knowledge. Quote 5C suggests that the Quranic discourse is more appropriate. It is a credible source for pledging as it is Noble. In Arabic, the term [kari:mun] is used to describe someone who is characterized by certain values such as kindness.It is also used in Semitic languages, such as Arabic and Hebrew to describe something like water which tends to be cool. Thus, it is welcoming a drink. To speak metaphorically, the Noble Quran, like cool water, is characterized by nobility, i.e. sincerity, and accessibility and attainability, say unlike the settings of the stars. Consequently, the Quranic discourse maintains the negation marker [la:] as a starter, verbal clue to advance a directive that reads: Don't swear.

\subsection{The ADM [ha:]}

In Arabic, the interjection-like phrase [ha:-'umu] is questionable. Traditionally, it is referred to as a verb-like noun phrase meaning 'Come' (see the English translation for quote 6A). More recent morphological as well as denotational theories, however, advocate that this morpheme, i.e. smallest unit of language that carries meaning, consist of [ha:] which is used for alarming, the glottis ['u] and the plural speech marker [mu]. The morpheme [h(a)] is usually used for polite requesting as in [hayya:] meaning (let's go), disquieting as in [sa-hin] meaning (be silent!) and laughing as in [Hhhh]. Glottal stops such as ['a, 'i and 'u] as well as geminated phonemes, i.e. double sound consonants, were and will be historically a matter of linguistic disagreement to the native speakers of Arabic. Here, it is probable that the glottal stop is used as stem extender. In the Quranic discourse, rules of recitation, however, attempts to reduce and smart them. Finally, the morpheme [-mu] is used for plural speech which is very common in Arabic. 
Exploring Discourse Markers in the Noble Quran: Some Verbal Clues that Facilitate Logical Hedging, Linguistic Interaction and Language Politeness

In quote 6A, the Quranic discourse presents a compound sentence where two equal ideas are presented. In the first, the discourse informs about someone who will be given his record in his right hand. In the second, the discourse reports that that person will immediately invite others to read his record.

Quote 6A [fa-'amma: man 'u:tiya kita:bahu bi-yami:nihi fa-yaqu:lu ha:'umu 'iqra'u: kita:biyah] AlHaqqah 69:20

(Then, as for him who is given his record in his right hand, he will say, 'Come, read my record.)

The predicate ['u:tiya] meaning (was given) argues for the relative pronoun [man] meaning (who), [kita:ba-hu] meaning (his record) and [bi-yami:nihi] meaning in (his right hand). The predicate is a three-place one. The predicate [fa-yaqu:lu] meaning (then he says) argues for the directive clause. It is important to note here that the interpreter of the Noble Quran (provided here) has perceived the second part as pseudo coordination. Therefore, the verse [ha:-ummu iqra'u: kita:biyah] is translated into English as (Come, read my record) meaning either (come and read my record) or (come to read my record). The former sustains a directive carried out by two VPs; the later maintains a directive for a purpose.

In quote 6A, the Quranic discourse presents a thrilling act. Anything placed to the right must be meaningful or thematic, so it must be good. In semantics, a key word that carries full meaning is always governed by the right hand-head rule and is often placed to the right (according to Chomsky). In the Islamic doctrine, certain themes related to motion, grooming habits, eating habits for example, are all encouraged by the right-hand organs. The Quranic discourse also manipulates misconducts of members of dysfunctional families according to a gender-oriented theory. It places females who practice illegal sex to the right of their counterpart the males. Differently, it places the males who commit theft to the right.

In the Quranic discourse, politeness is not only a verbal but also a behavioral act. In the verse, it sounds that the Noble Quran gives the turn to a winner, i.e. someone who received a good record to interact verbally in order to invite politely others to read what he has been given in his right hand. Thus, the ADM is perceived as 'well, come' or rather 'welcome' in modern English. In this sense, the atrophic but tactful term looks like the natural filler that shoots for language politeness. The context where the ADM is used is very positive.

To progress, quote 6B introduces the morpheme [halumma] which is roughly glossed as 'come' in English (see the interpretation for quote 6B). Traditionally, Arab linguists describe the morpheme as a verb-noun-like directive meaning 'Come!'. From an analytical perspective, the word may consist of the morpheme [ha], the stem extender [-1-], the speech nominal, plural marker [-um-] and the past tense inflectional marker [-a]. This analytical approach actually confirms what Arab linguists suggest about the morphological description of the word. However, it critically suggests (on the basis of the morpheme [ha-] in the previous section) that the lexeme [halumma] must mean 'welcome'.

In quote $6 \mathrm{~B}$, the word [halumma] takes place in a coordinated clause headed by [qad] which is glossed as 'verily' in English. The coordinated phrases [al-mu'awiqi:na] meaning (hinders) and [waalqa:'ili:na] glossed as (tellers or those who say) function as direct object. It is important to note here that noun phrases behave as verbs on the syntactic level in Arabic, so the reported NP can be advanced as [and they say to their brothers well come to us!] The verb-noun-like word [halumma] manifests itself as singular form as it lacks the plural form [u:] referring to brothers. The final commentary verse sounds ambiguous as it means either a few of them held fight or they held fight for short time.

Quote 6B [qad ya'lamu Allah-u al-mu'awwiqi:na minkum wa-alqa:'ili:na li-'ikhwanihim halumma 'ilayna: wa-la: ya'tu:na al-ba'sa 'illa: qali:la(n).] Al-Ahza:b 33:19

(Verily Allah knows those among you who hinder men and those who say to their brethren, 'Come to us;' and they come not to the fight but a little,)

In quote $6 \mathrm{~B}$, the predicate [ya'lamu] meaning [He knows] is assigned to argue for (Allah) and (hinders among you). Therefore, it is a two-place predicate. It also adds the coordinated phrase [wa-alqa'ili:na] as an argument. The predicate in the simple coordination clause which is glossed as (those who say) is also a two-place one. As NP phrases behave as VPs, the predicator [al-qa:'ili:na li-] argues for 
['ikhwa:nihim] meaning (their brothers) and [halumma 'ilayna:] glossed as (well, come to us). It is important to note here that the Quranic discourse avoids using [ta'a:lu:] which also means (come). This VP is very frequent in the Noble Quran elsewhere when the context is very negative. Ambiguity of meaning is also implicated for this exceptional group who keep not only welcoming or supporting others just by words, but also fighting either for a little or in few numbers.

It sounds that the noun-verb-like word is used schematically for verbal interaction. The Quranic discourse handles the turn for this group to reflect exactly what they are used to saying. That is to say that they are accustomed to explicating, i.e. expressing their directive of coming in a polite way. This helps explain why the directive [ta'alu:] meaning (come) is avoided in this verse. Using the form [halumma] in a context of war will enable a group of hippocratic people not to participate in a fight. Tactfulness of speech sustains respect of others. Consequently, the Quranic discourse hedges for the sense of welcoming others this group used to show. This hedging for the verbal action enables the Quranic discourse to manifest clearly the group's realistic social behaviours that few of them fight or they fight for a short time and that they are totally unkind. At the end of the quote, the discourse emphasizes that this group will behave verbally in peace (salaqu:kum bi-'alsinatin) meaning that they kept talking on how they will support you. They are just good at speaking.

\section{CONCLUSiONS}

The Quranic discourse tends to use ['in] as a marker or filler. Pragmatically, it inserts the ADM ['in] before one group rather than another to show solidarity with that group for some ontological reasons. The Quranic discourse also inserts the ADM to hedge or exclude for other possible cases that may manifest themselves as factual elements emerging from the issues under discussion on the logical level. There is some evidence that the Quranic discourse meets the needs of the new emerging Muslims and of disabled groups. Stylistically the Noble Quran uses the ADM to head some discourses so that the marker can hedge for specific meaning values. The language function of the quotes discussed in section 3.1 is unlikely to be informative. It is more likely to be phatic, expressive and meta-linguistic. Finally, the context where the ADM is inserted is crucial as it deals differently with either supernatural or physical power.

Besides, the minimal word ['an] is used as an ADM. In the quotes referred to above, the context is critical. It argues against torts, such as sexual abnormality and harassment and criminal acts, like murder. It has been noted that the ADM is inserted to enable linguistic interaction to refrain crimes. Cooperation usually fuels language interaction. It storms the brain with some ideas that redirects the flow of speech into a prevalent one. Besides, the native speaker of Arabic may perceive ['an] as discourse filler that helps impede time passage. It permits for a moment of comfort on the psychological level (and possibly of some hope on the logical level) that the misdeed under discussion is not going to take place. Though the language function of the quote propositions, i.e. openings, sounds informative, the consequences, it is both directive and interrogative in the consequence of the quotes utilized ['an] as an ADM.

The word [ma:] is also used as a marker in the Quranic discourse to convey one specific context. In the verses referred to, it has been found that two different verses manipulate the arrival of one group at Hell differently. On the syntactic level, one verse explicates that those people will be driven in groups. It is important to note here that the use of the passive VP be driven is intended to show both motion and manner. The other verse opens with the arrival itself. The linguistic features used to describe the arrival do not explicate how it takes place. However, it uses the ADM [ma:] to demonstrate for the way of that arrival. Therefore, it sounds that the ADM [ma:] modifies or hedges for the manner. In the closing part of quote $3 \mathrm{~A}$, linguistic interaction is enabled exceptionally between the group and their own organs. Language function tends to be mainly referential, performative and interrogative.

Moreover, the prepositional word [min] is used for quantification. In the quotes referred to in this study as well as in many other verses of the Quranic discourse, the quantifier is fairly frequently used to head a certain formula applying an Arabic exceptional style known as the exclusive style. This style operates a negation marker, such as [ma:] meaning (not) and an exclusive element (e.g. 'illa: meaning except or save) to exclude one thing, person, quality or entity of that person from those of the others. 
Exploring Discourse Markers in the Noble Quran: Some Verbal Clues that Facilitate Logical Hedging, Linguistic Interaction and Language Politeness

Throughout the Quranic discourse, this unique style flavors the insertion of [min] to the right of the NP being quantified. The NP under quantification is always indefinite. The prepositional phrase consisting of the preposition [min] and the NP function as a predicator. The proper noun (NP) Allah is used to argue exclusively for the potential of lordship (with lower case). The quantification element [min] mandates that the existence of any other gods having the bare minimum qualities of lordship is unlikely. The context the QDM tries to negotiate is perfect Lordship. This interpretation suggests that the QDM meets the Islamic ideology of monopoly. Language function swings between suasion and direction.

In addition, the Arabic negation marker [la:] has been recycled as a discourse marker at the logical level. In the Quranic discourse, a prefabricated formula made up of the ADM [la:], the VP ['uqsumu], the unstated first person singular pronoun ['ana:] meaning (I) an the bound prepositional morpheme [bi-] meaning (by) is used differently in a specific context. Schematically, negation is blocked at the semantic level. Thus, the statement is realized as positive one. Then, pledging is introduced in a great context related to the settings of stars, but excluded again under the condition of lack of knowledge. Finally, the Noble Quran is proposed for its nobility and attainability. The style used here sounds didactic. The language functions used here also look directive and informative. It is important to note here that language functions vary according to the context. For example, the Quranic verse [al-hamdu li-Allah-i Rabbi al-'alami:na] roughly glossed as (All praise belongs to Allah, Lord of all the worlds) is performative when recited in a prayer. The same verse is, however, expressive if it is used in a personal meeting with a friend. The same language function can be expressed by different language forms. Thus, the negative clause (Nay, I swear) can be interpreted as a directive or polite request that reads: Don't swear!).

Finally, the minimal word [ha] is prefixed in a few words in classic Arabic. Though atrophic in Modern Standard Arabic (MSA), these words were probably used by ancient native speakers of Arabic for welcoming. Generally speaking, those words have the syntactic features of both nouns and verbs. It is important to note here that geographic isolation leads to language conservatism. Besides, Arabia, where Arabs originated, is a large and rough place to live in. To survive, it is probable that Arabs derived those words for making peace with enemies and welcoming guests. Schematically and pragmatically, the Quranic discourse employs these words which are headed by [ha] to reveal practices as well as identities of people in specific situations. In this study, one critical analysis of the linguistic features of the ADM [ha] has revealed a group of people characterized by peacefulness of mind. The other shows another group of people enjoining evil.

\section{IMPLiCATIONS For PEDAgogy ANd RESEARCH}

To implicate for pedagogy, language instructors and linguists at the college level should draw their learners' attention to the impact of discourse markers on the discourse under comprehension. It has been found that some lexical and non-lexical fillers, such as 'yeah', 'well' and 'Mmm' for instance, are used to provide information, to present new topics and to reveal speaker's perception and realization of the information provided (Fischer and Brandt-Pook, 1998, pp. 107-113). Teachers should also regard discourse markers as formulaic sequences consisting of 'fixed combinations of words that can facilitate fluency of speech by making pauses shorter and less frequent' (Stewart, 2007). According to Wray (2005), discourse markers are prefabricated words or elements of words that are 'stored' in and 'retrieved whole from memory'. They can be detected in any language and can 'make up a large proportion of any discourse' (p.1). They can also be found in 'any length and can be used to express messages, functions, social solidarity and process information very fast without communication misunderstanding' (ibid. p.3)

Language researchers should also investigate the use of some Quranic odd words, such as [has-hasa] roughly glossed as 'come to light' (Yusuf 12:52) traditionally glossed as 'unfair' and [di:za:] (An-Najm 53:23). As they occur in some reported verses at the initial and final boundaries of a couple of utterances navigating very sensitive contexts linked to sexual harassment and criminal acts of sacrificing only females as embolalias. As the word suggests, embolalia (also known as filler, vocal filler and spacer) refers to false starts, hesitation forms, or any meaningless stammering words and phrases. As the Greek origin suggests, embolalia stands for something thrown in or stained in a perfect or near perfect way. Researchers need to examine the discourse where the words suggested 
Exploring Discourse Markers in the Noble Quran: Some Verbal Clues that Facilitate Logical Hedging, Linguistic Interaction and Language Politeness

above and any other word that is characterized by semantic and formation oddness as a Quranic marker attempting to convey certain context purposes.

Interpreters of the Quranic discourse into English should not be bound to the notion of sentence. They can go beyond to check the uses of certain words at the discourse level. It has been observed that the translators of the English version prefer to use the coordinators 'but' and 'or' as English equivalent. Though prevalent, the Noble Quran tends stylistically to use the linking word [lakinna] meaning 'but' for concession. Pragmatically, the holy Script of Islam inclines to employ [bal] for correction at broader discourse levels. In this sense, the word [bal] is likely to be felt as 'or rather' in modern English. Similarly, the Quranic discourse uses the phrase [bal] as polite term attempting to adjust or fix speech. Generally speaking, the Quranic discourse uses words technically and schematically, so it should be realized, analyzed, summarized in another language or even criticized from both a stylistic as well as a pragmatic perspective.

\section{REFERENCES}

[1] Al-Mahli, J. \& Al-Sayuti, J. Tafseer Al-Jalalayn. Available in Arabic at www.quran.al-islam.com [Accessed in May 2017].

[2] Al-Qurdubi, M. Tafseer Al-Qurdubi. Available in Arabic at www.quran.al-islam.com [Accessed in May 2017].

[3] Beatty, K. (2003) Teaching and Researching Computer-assisted Language learning. London: Longman.

[4] Bloor, M., \& Bloor, T. (2013). The practice of critical discourse analysis: An introduction. Routledge.

[5] Fairclough, N. (2013). Critical discourse analysis: The critical study of language. Routledge.

[6] Fairclough, N. (2010). Language and power. Pearson Education.

[7] Fairclough, N. (1995). Critical discourse analysis. The critical study of language. Language in social life series.

[8] Fairclough, N. (1992) Discourse and Social Change. Cambridge: Polity Press.

[9] Foucault, M. (1972). The discourse on language. Truth: Engagements across philosophical traditions, 315335.

[10] Fischer, K., \& Brandt-Pook, H. (1998). Automatic disambiguation of discourse particles. In Proc. of ColinACL'98 Workshop on Discourse Relations and Discourse Markers, Montreal, Canada (pp. 107-113).

[11] Guo, F. (2015). A Review of Discourse Markers from the Functional Perspective. Journal of Arts and Humanities, 4(4), 69.

[12] Henry, F., \& Tator, C. (2002). Discourses of domination: Racial bias in the Canadian English-language press. University of Toronto Press.

[13] Hinkel, E., \& Fotos, S. (Eds.). (2001). New perspectives on grammar teaching in second language classrooms. Routledge.

[14] Hum, M., Trihartanti, R. P., Hum, M., \& Damayanti, D. (2014). The Use of 'Oh'and 'Well'as

[15] Discourse Markers in Conversation of Bandung State Polytechnic Students. LEARN Journal: Language Education and Acquisition Research Network, 7(1), 22-44.

[16] Kearns, K. (2000) Semantics. New York: St. Martin's Press.

[17] Norbert Schmitt (editor: 2010). An Introduction to Applied Linguistics (2nd ed.). London: Hodder Education.

[18] Schmitt, N., \& Carter, R. (2004). Formulaic sequences in action. Formulaic sequences: Acquisition, processing and use, 1-22.

[19] Pennycook, A. (1994). Incommensurable discourses? Applied linguistics, 15(2), 115-138.

[20] Renkema, J. (2004). Introduction to discourse studies. John Benjamins Publishing.

[21] Stewart, O. (2007). An exploratory study into the intentionality of disfluency production.

[22] Van Dijk, T. A. (1998). Ideology: A multidisciplinary approach. Sage.

[23] Wang, Y. (2011). A Discourse-Pragmatic Functional Study of the Discourse Markers Japanese Ano and Chinese Nage. Intercultural Communication Studies, 20(2), 41.

[24] Wodak, R. (1999). Critical discourse analysis at the end of the 20th century. Research on Language \& Social Interaction, 32(1-2), 185-193.

[25] Wray, A. (2005). Formulaic language and the lexicon. Cambridge University Press. 
Exploring Discourse Markers in the Noble Quran: Some Verbal Clues that Facilitate Logical Hedging, Linguistic Interaction and Language Politeness

\section{APPENDIX A}

Can the Quranic Morphemes Traditionally Referred to as Extra Words be Interpreted as Verbal Discourse Markers?

\begin{tabular}{l|l|l|l|}
$\begin{array}{l}\text { Under } \\
\text { analysis }\end{array}$ & $\begin{array}{l}\text { Syntactic analysis: Descriptive } \\
\text { Producing meaning }\end{array}$ & $\begin{array}{l}\text { Semantic analysis: } \\
\text { Interpretive } \\
\text { Consuming meaning }\end{array}$ & $\begin{array}{l}\text { Schematic analysis: } \\
\text { Explanatory } \\
\text { Construing meaning }\end{array}$ \\
\hline
\end{tabular}

And We had established them in what We have established you not; and We gave them ears and eyes and hearts...

(1)Al-Ahaf 46:27

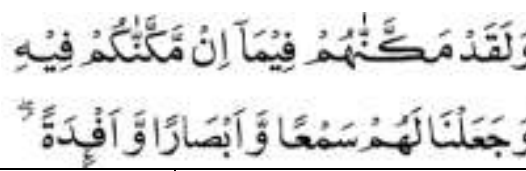

['in] $\mid \begin{aligned} & \text { The word under analysis serves no clear } \\ & \text { grammatical function on the sentential level. } \\ & \text { It also fits into no grammatical category. } \\ & \text { It however takes place in a relative clause } \\ & \text { [ma:] meaning [fi: al-athi:] meaning (in what). } \\ & \text { This clause is headed by a preposition and } \\ & \text { coordinated with another clause. }\end{aligned}$

The personal deictic pronoun [-hi] refers cataphorically, i.e. forward to address a category of things to be discussed later.

Therefore, the word takes place in a discourse, i.e. a unit of language above that of a sentence.

It is important to note here that [ma:] is a homophone that can be used as a relative pronoun and a negative marker.
The

[makkaNa: hum] is repeated twice. It means (established) and argues first for both (We) referring to Allah and (them) referring to a group of people, then again for (We), (you) referring to another group of people and (it) referring to something or a category of things.

The predicate is a twoplace and three-place VP, respectively.

It is important to note here that the interpreters of the Quranic discourse perceive ['in] as [ma:] meaning (not).

The word ['in] neither denotes [not] nor connotes the feeling of logical contradiction (of not).
For both a semantic and syntactic reason, the extra word ['in] is unlikely to be a categorematic, i.e. functional word that carries a full meaning or a syncategorematic, i.e. grammatical word that helps modify meaning.

As it turns speech from one group of people to another, it sounds that the Quranic discourse uses ['in] as a verbal clue or marker to argue for the visual, auditory and emotional abilities given to both groups.

It hedges for the potential deaf, blind and unkind members in both groups.

In case, it also keeps a positive face, i.e. respect for the potential disabled of on the basis of using this marker next to the right of- the you group.

Then they argued their affair among themselves and conferred in secret

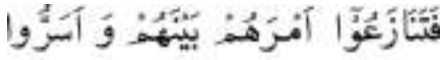

They said, 'Certainly these two are magicians, who

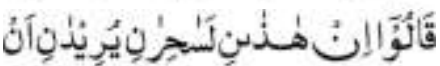

2TaHa 20:63-64

\begin{tabular}{|l|l|l|lr|}
\hline ['in] & $\begin{array}{l}\text { In Arabic, ['inna] or the unstressed form } \\
\text { ['in] is an endorsement element. }\end{array}$ & $\begin{array}{l}\text { On the discoursal level } \\
\text { (of both quotes), the } \\
\text { predicate }\end{array}$ & $\begin{array}{l}\text { As old Egyptians } \\
\text { failed to make up their } \\
\text { minds about the true }\end{array}$ \\
\hline
\end{tabular}


Exploring Discourse Markers in the Noble Quran: Some Verbal Clues that Facilitate Logical Hedging, Linguistic Interaction and Language Politeness

It is used to head the sentence when the style is nominal.

Grammatically, it is followed by two words functioning as subject and subject complement.

Syntactically, the NP functioning as subject is marked for the accusative case with [-a, an, -ayni, -i:na] when the subject is definite singular, indefinite singular, dual and plural, respectively.

The NP functioning as complement for the subject is differently marked for the nominative case with [-u, -un, -ani, -u:na] when the complement is definite singular, indefinite singular, dual and plural, respectively.

In quote 64 , the syntactic rules referred to above are blocked on the phonemic (but not graphemic) level though the unstressed endorsement element ['in] is furthered and sustained. meaning (he argued) is magician, it seems that assigned for [-u:] the Quranic referring to old Egyptians discourse reports what and [amra-hum] meaning (their affair) and [baynahum] meaning (among themselves).

So it is a three-place predicate.

The predicate [asarra] meaning (he conferred) is assigned for (them) and [an-najwa:] glossed as ( to themselves or in secret)

It is a two-place predicate.

The predicate [qa:la] meaning (he said) is assigned for [-u:] referring to (Egyptians who kept the fair) and a reporting clause.

This predicates is twoplace.

It reports the debate taking place secretly among Egyptians who suspects two people from Sons of Israel as magicians.

They demonstrate to or rather finally denounce Moses and his brother, Haroon as potential magicians.

The concept of magic is endorsed by the [la] also known as a slippery endorsement element in Arabic.

Demonstrating to the true magician (whether Moses, his brother or both) is carried out by [hatha:ni] which functions as an endophoric, textual reference (a quantified, human or non-human element).

Demonstrative pronoun must also show what belongs to someone, what belongs to others and what is neutral. was exactly going on.

It first handles the turn to that group to express their thoughts. Then it hedges by ['in] to mark verbally their disagreement about the true magician. Hedging here aims quantifying their speech.

It finally certifies what they agreed upon.

The graphemic clues sustained on the discoursal level probably show both how Arabs used to spell words and how they say words, but not in any case how words mean. 
And when Our messengers came to Lot, he was distressed on account of them and felt powerless with regard to them. And they said, 'Fear not, nor grieve; we will surely save thee and thy family except thy wife, who is of those who remain behind.

(3) A Al-'Ankabu:t 29:34

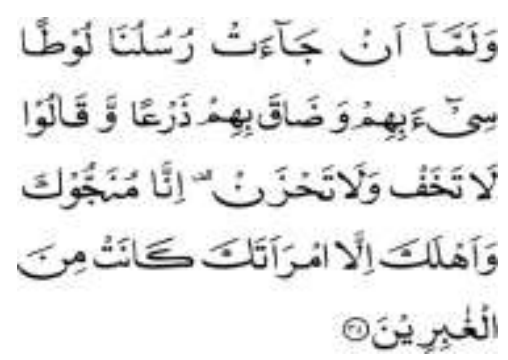

And when Our messengers came to Lot, he was grieved on account of them and felt helpless on their behalf and said, 'This is a distressful day.'

And his people came running towards him, trembling with rage; and before

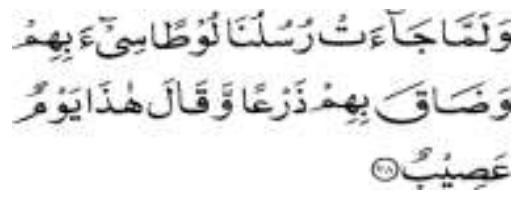
this too they used to do evil.

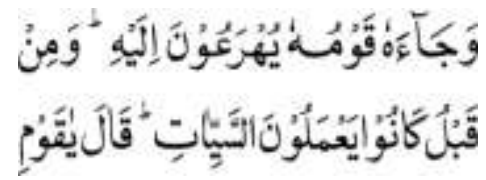

(3B Hud 11:78-79

\begin{tabular}{|c|c|c|c|}
\hline ['an] & $\begin{array}{l}\text { Though the opening of both quotes is } \\
\text { similar, verse } 34 \text { furthers ['an] as an } \\
\text { extra word. } \\
\text { This word takes place in the dependent } \\
\text { clause (and when ..) the clause continues } \\
\text { to present some events in sequence. } \\
\text { The sequence ends in a directive clause } \\
\text { (Fear not!). } \\
\text { Then it continues in a nominal style that } \\
\text { informs saving Noah and his family. } \\
\text { Finally it excludes his wife and other } \\
\text { people. }\end{array}$ & $\begin{array}{l}\text { The predicate [ja:'a] meaning } \\
\text { (he came) is assigned to } \\
\text { argue for [rusulu-Na] } \\
\text { meaning (our messengers) } \\
\text { and [lu:tan]. } \\
\text { It is a two-place predicate. } \\
\text { The predicate [si:'a] roughly } \\
\text { glossed as (mistreated or be } \\
\text { harassed by) argues only for } \\
\text { (-him] referring to (the } \\
\text { messengers). } \\
\text { It is a one-place predicate. } \\
\text { The predicate [da:qa] } \\
\text { glossed as (he felt powerless } \\
\text { regard) is assigned to argue } \\
\text { for both (he) referring to Lut } \\
\text { and (-him) referring to the } \\
\text { messengers. } \\
\text { So it is a two-place predicate. } \\
\text { The predicate } \\
\text { meaning (he said) is } \\
\text { assigned to argue for [-u:] } \\
\text { referring the messengers and } \\
\text { the directive [la: takhaf] } \\
\text { meaning (fear not). }\end{array}$ & $\begin{array}{l}\text { The word ['an] heads a } \\
\text { sequence of events in } \\
\text { which some guests } \\
\text { arrived, were } \\
\text { mistreated (by some } \\
\text { other locals) and the } \\
\text { host felt helpless. } \\
\text { As the dramatic } \\
\text { situation has reached } \\
\text { the peak on which the } \\
\text { host felt powerless to } \\
\text { protect his guests, the } \\
\text { Quranic discourse has } \\
\text { paved the way to give } \\
\text { the turn to the guests } \\
\text { themselves. } \\
\text { Taking the turn, the } \\
\text { guests redirect their } \\
\text { host not to feel panic } \\
\text { or sad and that they } \\
\text { will save their host } \\
\text { and his family except } \\
\text { the wife. }\end{array}$ \\
\hline
\end{tabular}


Exploring Discourse Markers in the Noble Quran: Some Verbal Clues that Facilitate Logical Hedging, Linguistic Interaction and Language Politeness

dost thou intend to kill me as thou didst kill a man yesterday? Thou only
intend est to become a tyrant in the land, and thou intendest not to be a peacemaker.'

(4)Al-Qasas 20:28

\begin{tabular}{|c|c|c|c|}
\hline ['an] & $\begin{array}{l}\text { The word ['an] takes place in a dependent } \\
\text { adverbial clause headed by [fa-lamma:] meaning } \\
\text { (when he). } \\
\text { The main (also known as matrix) clause is headed } \\
\text { by [qa:la] meaning (he said). This VP is a } \\
\text { reporting one. } \\
\text { The reported clause can be perceived as a } \\
\text { condemning interrogative. } \\
\text { In the dependent clause, the VP [ara:da] glossed as } \\
\text { (he made up his mind) is paradigmatic. Here, it } \\
\text { expresses a decision. Thus, it is cognitive. } \\
\text { In the main clause, the VP ['auri:du] meaning (Do } \\
\text { you intend?) is felt as a willingness verb aiming to } \\
\text { express a desire or want. } \\
\text { It is important to note here that the word under } \\
\text { investigation is homo-phonous. It only heads the } \\
\text { present but not past participle. } \\
\text { grammatical function nor language category. }\end{array}$ & $\begin{array}{l}\text { The predicate } \\
\text { [ara:da] meaning } \\
\text { (he decided) is } \\
\text { assigned to argue } \\
\text { for (the unstated [- } \\
\text { hwa]) referring to } \\
\text { Moses and the } \\
\text { (infinitival phrase } \\
\text { ['an yabtisha] } \\
\text { meaning (to kill } \\
\text { or Killing). } \\
\text { It is important to } \\
\text { note here that the } \\
\text { relative clause } \\
\text { headed by [bi- } \\
\text { alathi:] is a } \\
\text { specification for the } \\
\text { present participle } \\
\text { VP [yabtisha]. } \\
\text { This predicate is a } \\
\text { two-place one. } \\
\text { The reporting } \\
\text { predicate [qa:la] } \\
\text { meaning (he said) } \\
\text { is assigned to } \\
\text { argue for (the } \\
\text { unstated [huwa] } \\
\text { referring to an } \\
\text { Egyptian, the } \\
\text { exclamation } \\
\text { phrase ah, } \\
\text { Moses) and the } \\
\text { (interrogative } \\
\text { clause). } \\
\text { It is a three-place } \\
\text { predicate. }\end{array}$ & $\begin{array}{l}\text { This dramatic decision } \\
\text { has accelerated the } \\
\text { Quranic discourse to } \\
\text { give turn to the } \\
\text { Egyptian to interact. } \\
\text { Taking the turn, the } \\
\text { Egyptian has reminded } \\
\text { Moses that is going to } \\
\text { commit a second } \\
\text { crime, to be tyrant, } \\
\text { and not to be a } \\
\text { peacemaker. }\end{array}$ \\
\hline
\end{tabular}

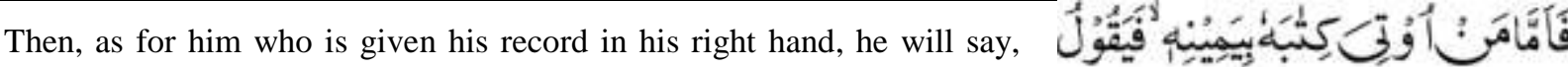
'Come, read my record.

5 Al-Haqqah 69:20

\begin{tabular}{|l|l|l|l|l|}
\hline [ha:'umu] & $\begin{array}{l}\text { The Quranic discourse presents a } \\
\text { compound sentence where two } \\
\text { equal ideas are presented. }\end{array}$ & $\begin{array}{l}\text { The predicate } \\
\text { ['u:tiya] meaning } \\
\text { as (was given) } \\
\text { argues for the } \\
\text { relative pronoun }\end{array}$ & $\begin{array}{l}\text { The Quranic discourse presents a } \\
\text { thrilling act. } \\
\text { Anything placed to the right must be } \\
\text { meaningful or thematic, so it must be }\end{array}$ \\
\hline
\end{tabular}


Exploring Discourse Markers in the Noble Quran: Some Verbal Clues that Facilitate Logical Hedging, Linguistic Interaction and Language Politeness

\begin{tabular}{|c|c|c|c|}
\hline & $\begin{array}{l}\text { In the first, the discourse informs } \\
\text { about someone who will be given } \\
\text { his record in his right hand. } \\
\text { In the second, the discourse } \\
\text { reports that that person will } \\
\text { immediately invite others to read } \\
\text { his record. } \\
\text { In Arabic, the interjection-like } \\
\text { phrase [ha:-umu] consists of } \\
\text { [ha:] which is used for alarming } \\
\text { like [ha-yya] meaning (let's), } \\
\text { verbal silence [sah] meaning (be } \\
\text { silent!) and laughing. } \\
\text { [-ummu] is used for plural } \\
\text { speech. }\end{array}$ & 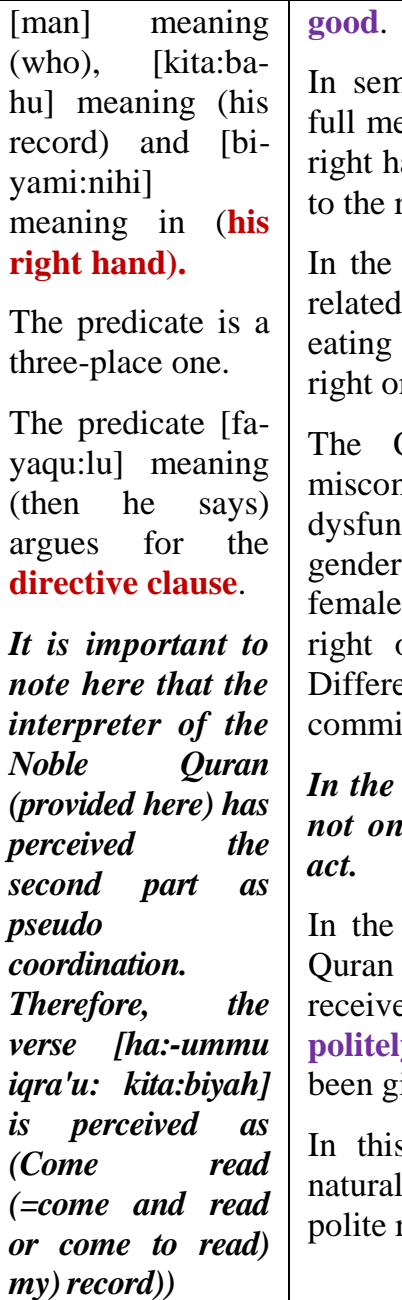 & $\begin{array}{l}\text { antics, a key word that carries } \\
\text { aning is always governed by the } \\
\text { nd-head rule and is often placed } \\
\text { ght (according to Chomsky). } \\
\text { Islamic doctrine, certain themes } \\
\text { to motion, grooming habits, } \\
\text { abits.. etc. is encouraged by the } \\
\text { gans. } \\
\text { uranic discourse manipulates } \\
\text { ducts of members } \\
\text { tional families according to a } \\
\text { oriented theory. It places } \\
\text { who practice illegal sex to the } \\
\text { f their counterpart the males. } \\
\text { ntly, it places the males who } \\
\text { theft to the right. } \\
\text { Quranic discourse, politeness is } \\
\text { ly verbal but also a behavioral } \\
\text { verse, it sounds that the Noble } \\
\text { gives the turn to someone who } \\
\text { d a good record to invite } \\
\text { others to read what he has } \\
\text { ven in his right hand. } \\
\text { sense, the term looks like a } \\
\text { equest. }\end{array}$ \\
\hline \multicolumn{4}{|c|}{$\begin{array}{l}\text { Verily Allah knows those among you who hinder men and those who } \\
\text { say to their brethren, 'Come to us;' and they come not to the fight but a } \\
\text { little, } \\
\text { 6Al-Ahza:b 33:19 }\end{array}$} \\
\hline [halumma] & $\begin{array}{l}\text { The word [halumma] takes place in a } \\
\text { coordinated clause headed by [qad] } \\
\text { which is glossed as verily in English. } \\
\text { The coordinated phrases [al- } \\
\text { mu'awiqi:na] meaning (hinders) and } \\
\text { [wa-alqa:'ili:na] glossed as (tellers or } \\
\text { those who say) function as direct } \\
\text { object. }\end{array}$ & $\begin{array}{l}\text { The predicate [ya'lamu] } \\
\text { meaning [He knows] is } \\
\text { assigned to argue for } \\
\text { (Allah) and (hinders } \\
\text { among you). } \\
\text { It is a two-place } \\
\text { predicate. } \\
\text { It also adds the } \\
\text { coordinated phrase [wa- } \\
\text { alqa'ili:na] as an } \\
\text { argument. } \\
\text { The predicate in the } \\
\text { simple coordination } \\
\text { clause which is glossed } \\
\text { as (those who say) is } \\
\text { also a two-place one. } \\
\text { As NP phrases behave } \\
\text { as VPs, the predicator } \\
\text { [al-qa:'ili:na li-] argues }\end{array}$ & $\begin{array}{l}\text { It sounds that the VP-like word } \\
\text { is used schematically for } \\
\text { verbal interaction. } \\
\text { The Quranic discourse } \\
\text { handles the turn for this } \\
\text { group to reflect exactly what } \\
\text { they are used to saying. } \\
\text { That is to say they used to } \\
\text { explicate, i.e. express a } \\
\text { directive in a polite term. } \\
\text { This helps explain why the } \\
\text { directive [ta'alu:] meaning } \\
\text { (come) is avoided here. } \\
\text { Using the form [halumma] } \\
\text { sustains politeness that others } \\
\text { can perceive, } \\
\text { So the Quranic discourse }\end{array}$ \\
\hline
\end{tabular}


Exploring Discourse Markers in the Noble Quran: Some Verbal Clues that Facilitate Logical Hedging, Linguistic Interaction and Language Politeness

\begin{tabular}{|c|c|c|c|c|c|}
\hline & \multicolumn{2}{|c|}{$\begin{array}{l}\text { The final commentary verse sounds } \\
\text { ambiguous as it means either a few } \\
\text { of them held fight or they held fight } \\
\text { for short time. }\end{array}$} & $\begin{array}{l}\text { for ['ikhwa:nihim] } \\
\text { meaning } \\
\text { brothers) } \\
\text { [halumma 'ilayna:] } \\
\text { glossed as (well, come } \\
\text { to us). } \\
\text { It is important to note } \\
\text { here that the Quranic } \\
\text { discourse avoids using } \\
\text { [ta'a:lu:] which also } \\
\text { means (come). This VP } \\
\text { is very frequent in the } \\
\text { Noble Quran elsewhere } \\
\text { when the context is } \\
\text { very negative. } \\
\text { Ambiguity of meaning } \\
\text { is also implicated for } \\
\text { this exceptional group } \\
\text { who keep not only } \\
\text { welcoming or } \\
\text { supporting others just } \\
\text { by words, but also } \\
\text { fighting either for a } \\
\text { little or in few numbers. }\end{array}$ & \multicolumn{2}{|c|}{$\begin{array}{l}\text { This hedging for the verbal } \\
\text { action enables the Quranic } \\
\text { discourse to manifest clearly } \\
\text { the group's realistic social } \\
\text { behaviours that few of them } \\
\text { fight or they fight for a short } \\
\text { time and that they are totally } \\
\text { unkind. } \\
\text { At the end of the quote, the } \\
\text { discourse emphasizes that this } \\
\text { group will behave verbally in } \\
\text { peace (salaqu:kum bi- } \\
\text { 'alsinatin) meaning they talk on } \\
\text { and on and on how they will } \\
\text { support you. They are just } \\
\text { good at speaking. }\end{array}$} \\
\hline \multicolumn{6}{|c|}{$\begin{array}{l}\text { Till, when they reach it, their ears and their eyes and their skins will bear } \\
\text { witness against them as to what they had been doing. }\end{array}$} \\
\hline \multicolumn{6}{|c|}{$\begin{array}{l}\text { And they will say to their skins: 'Why bear ye witness against us?' They will } \\
\text { say: 'Allah has made us to speak as He has made everything else to speak. } \\
\text { And He it is Who created you the first time, and unto Him have you been } \\
\text { brought back. } \\
\text { DAs-Sajdah 41:21-22 }\end{array}$} \\
\hline [ma:] & $\begin{array}{l}\text { This word takes place in } \\
\text { adverbial clause of time } \\
\text { headed by [hatta:] } \\
\text { meaning until which } \\
\text { shows the end point of } \\
\text { time and the conditional } \\
\text { clause headed by [itha:] } \\
\text { meaning (when). } \\
\text { The main clause is a } \\
\text { verbal sentence where } \\
\text { three elements consisting } \\
\text { of ears, eyes and skins } \\
\text { function as coordinated } \\
\text { direct objects for the VP } \\
\text { [shaid] meaning (bear } \\
\text { witness). } \\
\text { The second verse begins } \\
\text { with a reporting VP }\end{array}$ & $\begin{array}{l}\text { The predi } \\
\text { motion V } \\
\text { (they) and } \\
\text { is a two-p } \\
\text { The predi } \\
\text { witness a } \\
\text { (ears), (ey } \\
\text { clause, so } \\
\text { In the } \\
\text { [ya'mulu], } \\
\text { for [-u:] } \\
\text { one-place } \\
\text { It is impo } \\
\text { relation th } \\
\text { (bear wit } \\
\text { (ears, eye } \\
\text { part of wh }\end{array}$ & $\begin{array}{l}\text { ate [ja'a:] meaning (he can } \\
\text { P. It argues for [-u:] refer } \\
\text { [-ha:] referring to (the Hel } \\
\text { ace predicate. } \\
\text { ate [shahida 'ala:] meaning } \\
\text { gainst) is assigned to ars } \\
\text { es) and (skins) and the r } \\
\text { it is a two-place predicate. } \\
\text { elative clause, the pr } \\
\text { meaning (he does) argue } \\
\text { hich refers to (them), so } \\
\text { redicate. } \\
\text { tant to note here that the m } \\
\text { e verse sustains between } \\
\text { ess against) and the arg } \\
\text { and skins) is a merony } \\
\text { le one. }\end{array}$ & $\begin{array}{l}\text { e) is a } \\
\text { ring to } \\
\text { ), so it } \\
\text { (bear } \\
\text { ue for } \\
\text { elative } \\
\text { edicate } \\
\text { s only } \\
\text { it is a } \\
\text { eaning } \\
\text { he VP } \\
\text { aments } \\
\text { m, i.e. }\end{array}$ & $\begin{array}{l}\text { In Standard Arabic, } \\
\text { the morpheme [ma:] is } \\
\text { a homophonous word. } \\
\text { It is used for } \\
\text { exclamation, } \\
\text { negation and } \\
\text { interrogation. } \\
\text { In the syntactic level, } \\
\text { none of these } \\
\text { processes sounds } \\
\text { operable. } \\
\text { Though the verse does } \\
\text { not entail any } \\
\text { anomalousness, i.e. } \\
\text { semantic oddness, } \\
\text { using parts of the body } \\
\text { other than the organs } \\
\text { of the articulation }\end{array}$ \\
\hline
\end{tabular}


Exploring Discourse Markers in the Noble Quran: Some Verbal Clues that Facilitate Logical Hedging, Linguistic Interaction and Language Politeness

\begin{tabular}{|c|c|c|c|c|}
\hline & \begin{tabular}{l|l} 
[qa:la] meaning (he said). & In \\
as \\
of \\
Then it continues with & inc \\
the same reporting verb & VP \\
where a relative clause is & In \\
used. & me \\
& jul \\
the \\
The verse ends in a & wit \\
nominal style. & pre \\
& In \\
The nominal style aims at & ala \\
loading certain meanings & ref \\
related to ontology, i.e. & (us \\
creation and recreation. & Th \\
& ref \\
& sen \\
& Th \\
& me \\
& anc \\
& In \\
& als \\
& (ev \\
& It \\
arg \\
exi \\
int \\
sor
\end{tabular} & $\begin{array}{l}\text { ny way, it is not anomalous, } \\
\text { his category has the semant } \\
\text { humans or animates, so the } \\
\text { uded within the semantic fea } \\
\text { the second verse, the predi } \\
\text { aning (he said) argues for } \\
\text { 1:di-him] referring to (their } \\
\text { interrogative (why did } \\
\text { ness against us?), so it is } \\
\text { dicate. } \\
\text { he interrogative, the predica } \\
\text { ] meaning (bear witness ag } \\
\text { rring to (the skins) and [-na] } \\
\text {, so it is a three-place predica } \\
\text { predicate [qa:la] argues } \\
\text { rring to (the skins) and the w } \\
\text { rence, so it is a two-place pre } \\
\text { hething then Allah made that } \\
\text { predicate of the sentenc } \\
\text { aning (made speak) argues } \\
\text { the relative clause). } \\
\text { he relative clause, the predica } \\
\text { argues for the unstated (everything) is a univ } \\
\text { erything ). }\end{array}$ & $\begin{array}{l}\text { i.e. strange } \\
\text { ic features } \\
\text { se NPs are } \\
\text { tures of the } \\
\text { cate [qa:la] } \\
\text { Prep-P [li- } \\
\text { skins) and } \\
\text { you bear } \\
\text { two-place } \\
\text { te [shahida } \\
\text { ainst), [-tu] } \\
\text { referring to } \\
\text { te. } \\
\text { for [-u:] } \\
\text { hole verbal } \\
\text { dicate. } \\
\text { e ['antaqa] } \\
\text { for (Allah) } \\
\text { Ite ['antaqa] } \\
\text { Allah) and } \\
\text { m speak. } \\
\text { ersal, non- } \\
\text { that the } \\
\end{array}$ & $\begin{array}{l}\text { system breaks the } \\
\text { norms of speech and } \\
\text { witness. } \\
\text { Therefore, it sounds } \\
\text { that the Quranic } \\
\text { discourse paves the } \\
\text { way for a strange } \\
\text { way of interaction } \\
\text { between a group of } \\
\text { people and their own } \\
\text { skins. } \\
\text { In this sense, the word } \\
\text { [ma:] is actually a } \\
\text { verbal discourse } \\
\text { marker or a verbal } \\
\text { clue having the } \\
\text { meaning value of } \\
\text { exclamation and } \\
\text { aiming to introduce a } \\
\text { different way of } \\
\text { witness in which } \\
\text { everything such as } \\
\text { skins, eyes or ears can } \\
\text { be logically made } \\
\text { speak as Allah can } \\
\text { make them do so. }\end{array}$ \\
\hline \multicolumn{5}{|c|}{$\begin{array}{l}\text { And to Midian } \\
\text { worship Allah; y } \\
\text { come to you fro } \\
\text { diminish not unt } \\
\text { after it has been s } \\
\text { 8 Al-'Ara:f 7:86 }\end{array}$} \\
\hline$[\mathrm{min}]$ & $\begin{array}{l}\text { The quote begins with a } \\
\text { Prep-P which is used as a } \\
\text { discourse linking phrase in a } \\
\text { chapter that narrates shortly } \\
\text { the stories of some Prophets. } \\
\text { The quote briefly narrates the } \\
\text { story of Sha'ib who was sent } \\
\text { to his peoples of Madian. } \\
\text { The quote shifts to report } \\
\text { what the Prophet said to his } \\
\text { own people. }\end{array}$ & $\begin{array}{l}\text { The unstated predicate } \\
\text { ['arsala 'ila:] meaning (he } \\
\text { sent to) argues for the } \\
\text { unstated [-Na] -omitted for } \\
\text { a rhetorical, i.e. elipsis } \\
\text { purpose) which refers to } \\
\text { (Allah), Madian referring } \\
\text { to the place where (those } \\
\text { people) live and Shu'aib, } \\
\text { so it is a three-place } \\
\text { predicate. } \\
\text { The change from place to } \\
\text { people aims at widening }\end{array}$ & $\begin{array}{l}\text { The inser } \\
\text { exceptiona } \\
\text { quantifyir } \\
\text { gods. } \\
\text { In Stand } \\
\text { morpheme } \\
\text { (some) in } \\
\text { Lack of } \\
\text { conveys } \mathrm{t} \\
\text { meaning g } \\
\text { On the lo } \\
\text { of the p } \\
\text { switch th }\end{array}$ & $\begin{array}{l}\text { ion of [min] in the } \\
\text { inclusive style aims at } \\
\text {-if any- other potential } \\
\text { rd Arabic, the free } \\
\text { [min] can be glossed as } \\
\text { lodern English. } \\
\text { this morpheme often } \\
\text { e kind as in ['ila:hun] } \\
\text { d. } \\
\text { ical level, the insertion } \\
\text { epos-ition [min] helps } \\
\text { kind into the bare }\end{array}$ \\
\hline
\end{tabular}


Exploring Discourse Markers in the Noble Quran: Some Verbal Clues that Facilitate Logical Hedging, Linguistic Interaction and Language Politeness

\begin{tabular}{|c|c|c|c|c|c|}
\hline & \multicolumn{2}{|c|}{$\begin{array}{l}\text { The quote goes on to give } \\
\text { some directives to those } \\
\text { people }\end{array}$} & $\begin{array}{l}\text { meaning. } \\
\text { The predicate [qa:la] } \\
\text { meaning (he said) argues } \\
\text { for the interjection phrase } \\
\text { [ya: qawmi:] meaning (Oh, } \\
\text { my people), the directive } \\
\text { clause, and the exclusive } \\
\text { clause, so it is a three- } \\
\text { place predicate. } \\
\text { The predicate ['ibud] } \\
\text { meaning (worship) argues } \\
\text { for [-u:] referring to } \\
\text { (people) and (Allah), so it } \\
\text { is a two-place one. } \\
\text { In the exclusive, nominal } \\
\text { clause, the bound } \\
\text { morpheme [-H] referring } \\
\text { to (Allah) is the predicator } \\
\text { which argues for [illah] } \\
\text { referring to (any other } \\
\text { potential gods), so it is a } \\
\text { one-place predicate. }\end{array}$ & \multicolumn{2}{|c|}{$\begin{array}{l}\text { Therefore, the insertion of this } \\
\text { morpheme hedges not only for the } \\
\text { absence of other gods save Allah } \\
\text { but also for the scarcity of finding } \\
\text { semi or mini gods. } \\
\text { Absent the inserted clause [min } \\
\text { 'ila:hin] glossed as (some god), the } \\
\text { meaning is conveyed and only } \\
\text { for Lordship. } \\
\text { It is important to note here that the } \\
\text { hedging clause can be referred to } \\
\text { as a disjunct on the syntactic } \\
\text { level. } \\
\text { Disjunct clauses can be isolated on } \\
\text { the discourse level as they are used } \\
\text { as verbal clues to mark or hedge } \\
\text { for other possible ideas. }\end{array}$} \\
\hline $\begin{array}{l}\text { Nay, } \\
\text { inde } \\
\text { 9Al }\end{array}$ & $\begin{array}{l}\text { by the shooting of } \\
\text { le Qur'an, } \\
56: 76-78\end{array}$ & he stars & And, indeed, that is a grand & ath, if $y$ & ou only knew — That this is \\
\hline [la:] & 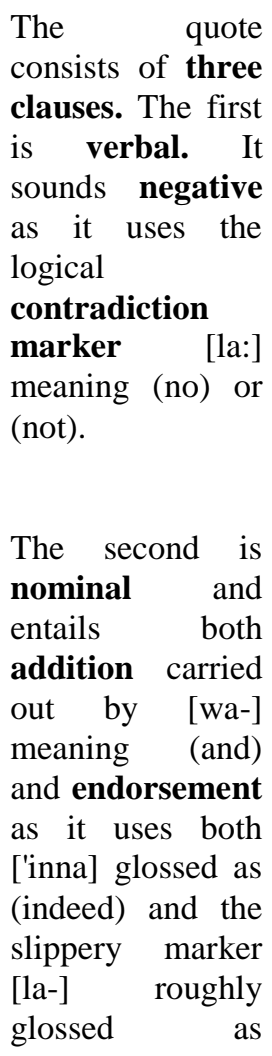 & $\begin{array}{l}\text { Though it } \\
\text { don't swe } \\
\text { speakers o } \\
\text { explain w } \\
\text { discourse }\end{array}$ & $\begin{array}{l}\text { entails contradiction, the c } \\
\text { ar) is perceived -by the } \\
\text { Arabic- as (I swear). This als } \\
\text { y the interpreters of the } \\
\text { onsider it as a disjunct. }\end{array}$ & $\begin{array}{l}\text { ote (I } \\
\text { native } \\
\text { helps } \\
\text { uranic } \\
\text { simu] } \\
\text { or the } \\
\text { nd the } \\
\text { stars), }\end{array}$ & $\begin{array}{l}\text { In turn, pledging is a great } \\
\text { act as it builds on } \\
\text { providing some true, } \\
\text { sincere and credible } \\
\text { sources. } \\
\text { Therefore, pledging by the } \\
\text { shooting stars is unlikely } \\
\text { as it lacks true and } \\
\text { accessible knowledge. }\end{array}$ \\
\hline
\end{tabular}


Exploring Discourse Markers in the Noble Quran: Some Verbal Clues that Facilitate Logical Hedging, Linguistic Interaction and Language Politeness

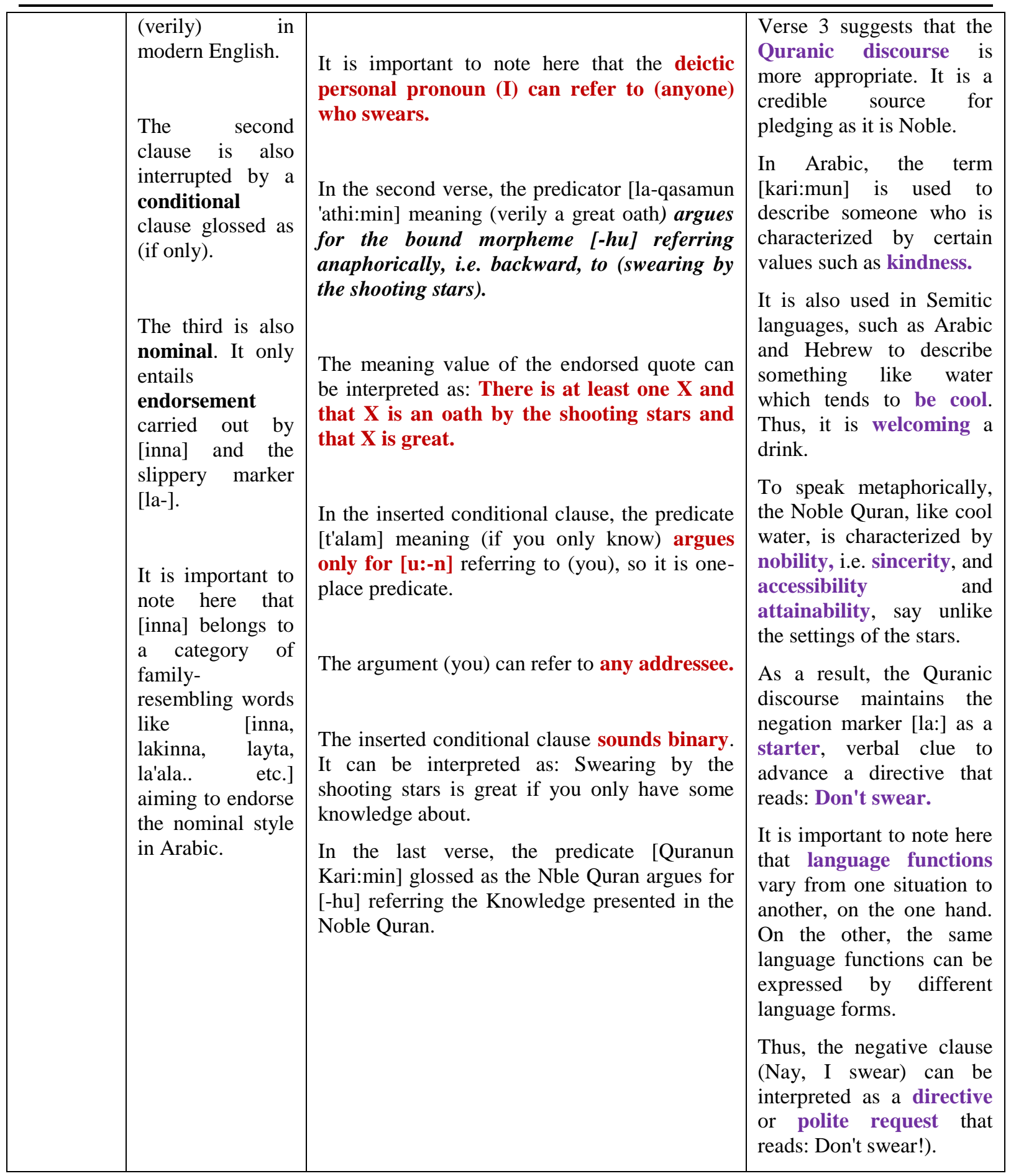




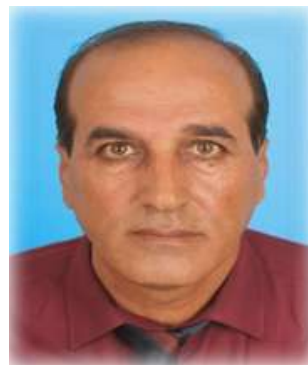

Mr. Sami A. Al-Heeh, has been working as a full-time lecturer at the Department of English, Palestine Ahliya University College, Bethlehem since 2007. Mr. Al-Heeh has a Master's degree in TESOL, UK. He is a Program Coordinator and a linguistics instructor. Mr. Al-Heeh also worked as an EFL teacher from 1994-2006 in both the public and private sectors. Since $2014 \mathrm{Mr}$. Al-Heeh has been researching specific issues in the Quranic Discourse from a pragmatic and stylistic perspectives.

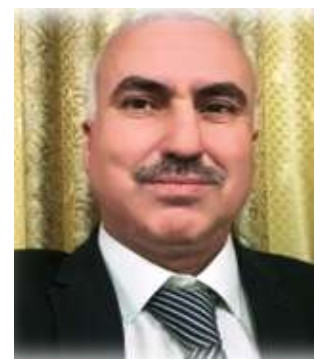

Dr. Mahmoud J. Itmeizeh, has been teaching English Language in Palestine Universities since 2000. He has Ph.D. in Methods of Teaching English Language / Instructional Technology from Institute of Arab Research and Studies, Cairo (Egypt) in 2008. He is currently an assistant professor in the department of Applied English at Palestine Ahliya University. Dr. Mahmoud published many researchers in different international refereed journals, he also participated in many local and international conferences.

Citation: Sami Al-Heeh, Mahmoud Itmeizeh, "Exploring Discourse Markers in the Noble Quran: Some Verbal Clues that Facilitate Logical Hedging, Linguistic Interaction and Language Politeness." International Journal on Studies in English Language and Literature (IJSELL), vol 5, no. 12, 2017, pp. 1-25. doi:http://dx.doi.org/10.20431/2347-3134.0512001.

Copyright: (C) 2017 Authors. This is an open-access article distributed under the terms of the Creative Commons Attribution License, which permits unrestricted use, distribution, and reproduction in any medium, provided the original author and source are credited. 